\title{
Contingent Capital with Sequential Triggers
}

\author{
WULF A. KAAL* \\ CHRISTOPH K. HENKEL**
}

* Associate Professor, University of Saint Thomas School of Law (Minneapolis). The Author wishes to thank the 2011-2012 selection committees of the AALS Section on Securities Regulation and the AALS Section on Financial Institutions and Consumer Financial Services. He also acknowledges the assistance of his colleagues, especially John C. Coffee, Jr., Michelle Harner, Christian Kirchner, Lisa M. Fairfax, the participants of the workshop on business law at the Southeastern Association of Law Schools 2011, and the participants at a January 2012 colloquium at Villanova University School of Law. He is grateful for outstanding research assistance from Ms. Caroline Kunz Ivanov and Ms. Katherine M. Eckberg.

** Assistant Professor, Mississippi College School of Law. Assessor iur., LL.M., S.J.D., University of Wisconsin Law School. Professor Henkel teaches Domestic and International Commercial Law, Bankruptcy, and European Union Law. He has specific experience in cross-border transactions, international litigation, and arbitration. The Author would like to thank Professors Jason Kilborn, Eric. F. Gerding, Anna Gelpern, William Sjostrom, Mehrsa Baradaran, Heidi M. Schooner, Elizabeth Trujillo, Jason Yackee, Claire R. Kelly, Sungjoon Cho, and David Zaring for their comments and suggestions. The Author would also like to thank the organizers and participants of the Section Meetings on Securities Regulation and Financial Institutions and Consumer Financial Services at the 2012 Annual Meeting of the American Association of Law Schools in Washington, D.C., as well as the organizers and participants of the workshop on Post-Crisis International Financial Regulation: Fragmentation, Harmonization and Coordination of the American Society of International Law at Suffolk University School of Law in December 2011. Finally, the Author acknowledges the research assistance of Ms. Caroline Kunz Ivanov on this project. The completion of this Article would not have been possible without her help and dedication. 


\section{TABLE OF CONTENTS}

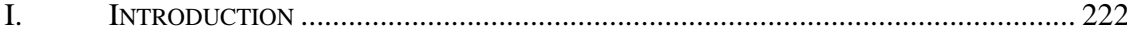

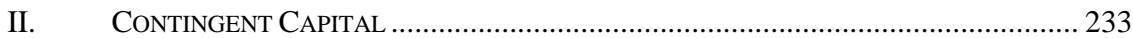

A. Potential for Reform and Financial Stability ....................................... 234

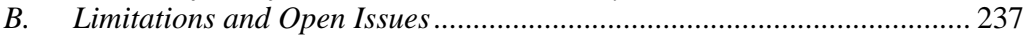

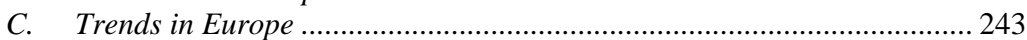

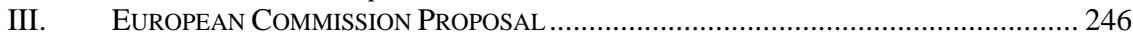

A. The Comprehensive Approach ............................................................... 247

B. The Targeted Approach ....................................................................... 248

IV. SEQUENTIAL TRIGgERS AS PART OF THE EUROPEAN COMMISSION'S

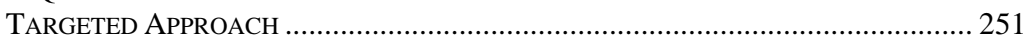

A. First Trigger: Debt-Equity Conversion .............................................. 252

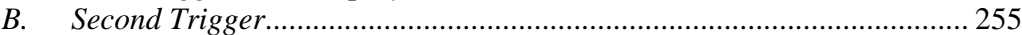

1. Objective Automatic Institution-Specific Trigger............................. 256

2. Voting Rights Increase for CCS Holders ....................................... 257

a. Law of EU Member States .................................................... 258

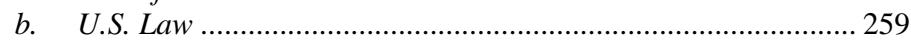

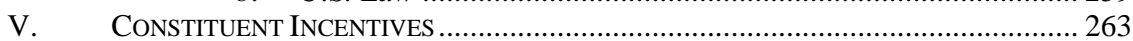

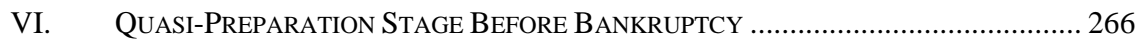

A. Debtor in Possession and Creditor's Committees ................................. 267

B. Contingent Capital in Prepackaged Bankruptcy

Plans and Preplan Sales .............................................................. 270

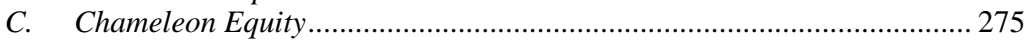

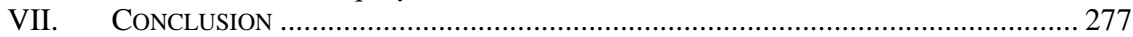

\section{INTRODUCTION}

At the height of the financial crisis, many countries saw no other alternative than bailing out some of their most prominent financial institutions. ${ }^{1}$ Bank failure or the winding up of banks through the then-

1. See Kenneth Ayotte \& David A. Skeel, Jr., Bankruptcy or Bailouts?, 35 J. CoRp. L. 469, 470 (2010) (noting that although it would be difficult to extract a consistent policy from the government's response to failing banks, a "guiding principle" became a preference for bailouts over bankruptcy and its attendant consequences and that "Lehman proved that you cannot let a large internationally active firm fail in the middle of a financial crisis" (quoting Interview by Scott Pelley with Ben Bernanke, Chairman, Fed. Reserve, on 60 Minutes (CBS television broadcast Mar. 15, 2009), available at http://www.cbsnews.com/stories/2009/03/12/60minutes/main4862191.shtml) (internal quotation marks omitted)); Wulf A. Kaal \& Richard W. Painter, Initial Reflections on an Evolving Standard: Constraints on Risk Taking by Directors and Officers in Germany and the United States, 40 SETON Hall L. REV. 1433, 1435 (2010) (discussing several German banks that became involved in asset-backed commercial paper (ABCP) programs). Deutsche Bank, IKB, and SachsenLB were the leading bank sponsors with outstanding ABCP. This resulted in the eventual German government bailout of IKB and WestLB, which had to be bailed out four times. See George A. Walker, Financial Crisis-U.K. Policy and Regulatory Response, 44 INT'L LAW. 751, 753-54 (2010) (commenting that in the United Kingdom, the bailouts began with the 
existing channels of insolvency was perceived as the second-best solution. ${ }^{2}$ Governments were hesitant to treat failing banks and other financial institutions through their regular insolvency procedures. ${ }^{3}$ Defaulting to insolvency proceedings would have imposed significant losses on creditors and shareholders. Winding up banks through insolvency could also have triggered bank runs ${ }^{4}$ and panic in financial markets. ${ }^{5}$

Legislators worldwide recognize that avoiding a repeat of the financial crisis of 2008-2009 is an important legislative objective. ${ }^{6}$ Across jurisdictions, the proposals to achieve that objective are multifold. Regulation of financial institutions has emerged as one of the priorities. ${ }^{7}$

Bank of England eventually nationalizing Northern Rock Bank in 2008, followed the next year by the government announcing a second support package for struggling banks).

2. See Ayotte \& Skeel, supra note 1, at 470-71.

3. See DAVID SKeEl, THE NEW FinANCIAL DEAL: Understanding THE DodDFRANK ACT AND ITS (UNINTENDED) CONSEQUENCES 84-85 (2011) (arguing that the thenexisting channels of bankruptcy would have sufficed to treat failing banks and noting that the Dodd-Frank Act instructs the General Accountability Office to conduct a study on contingent capital and to begin using it when the study is completed). Although Skeel refers to contingent capital as a "promising strategy," he points out some limitations. Contingent capital will not be "especially effective if the bank can easily manipulate its capital, or if capital requirements are low." Id. at 85. Skeel also recognizes that "[c]ontingent capital also will not protect against a sudden collapse, as in the cases of Bear Stearns and AIG ... . [because] new capital would come too late to break the fall.” Id.

4. See Walker, supra note 1, at 753-54 (pointing out that though Northern Rock did not have significant exposure to the U.S. subprime market, it was dependent on wholesale funding from interbank markets within the United Kingdom). Northern Rock's funding diminished with the reduction of wholesale lending. The lack of funding was leaked to the public through a British Broadcasting Corporation report, thus precipitating the bank run. Id.

5. See id.; Mark J. Roe, The Derivatives Market's Payment Priorities as Financial Crisis Accelerator, 63 STAN. L. REV. 539, 564 (2011) (recognizing that "one financial failure could induce another and, like dominoes, the financial system could collapse").

6. The Dodd-Frank Wall Street Reform and Consumer Protection Act was enacted with the intention of preventing another crisis. 155 CoNG. REC. H14418-03, H14420 (daily ed. Dec. 9, 2009) (statement of Rep. Paul Kanjorski) (“[T]his body will have the opportunity to . . . fundamentally change the way Wall Street and large financial institutions operate. For roughly two years, we have endured a severe crisis that exposed vulnerabilities in our system for overseeing the financial sector and demonstrated the perils of deregulation.”); HM TREASURY, A NEW APPROACH TO FINANCIAL REgUlATION: JUDGMENT, FOCUS AND STABILITY 62 (2010), available at http://www.hm-treasury.gov. $\mathrm{uk} / \mathrm{d} / \mathrm{consult}$ _financial_regulation_condoc.pdf ("The policy objective is to reform the regulatory system for financial services to avoid a repeat of the financial crisis.").

7. See, e.g., Dodd-Frank Wall Street Reform and Consumer Protection Act §§ 805, 808, 12 U.S.C. §§ 5464, 5467 (Supp. IV 2010) (containing a section titled "Examination of and enforcement actions against financial institutions subject to standards for designated activities" and providing that the relevant agency must "prescribe risk management standards”). 
The European Union (EU) Commission and the U.S. Congress invest heavily in regulatory oversight, preventive controls, and early intervention. ${ }^{8}$ National legislators in the United States and the European Union have proposed regulatory schemes to satisfy politically driven demands for regulation. Countries that lack a legal framework for dealing with failing banks and other financial institutions are considering "resolution regimes" to address the regulatory shortcomings evidenced by the crisis. In an attempt to make banks and other financial institutions less likely to fail or, if failure seems inevitable, less likely to affect other institutions or the taxpayers, the Financial Stability Board (FSB), the EU Commission, and the U.S. Congress have already set up resolution regimes. ${ }^{9}$

Contingent capital would help facilitate the efficient restructuring and resolution of failing financial institutions. ${ }^{10}$ Contingent capital is the predefined conversion of financial institutions' debt securities upon a triggering event into equity securities. ${ }^{11}$ Pending contingent capital

8. See DG Internal Mkt. \& Servs., Technical Details of a Possible EU FRAMEWORK FOR BANK RECOVERY AND RESOlUTION: WORKING DOCUMENT 1 (2011) [hereinafter DG WORKING DOCUMENT], available at http://ec.europa.eu/internal_market/ consultations/docs/2011/crisis_management/consultation_paper_en.pdf; see also DoddFrank Wall Street Reform and Consumer Protection Act tit. IV, Pub. L. No. 111-203, 124 Stat. 1376, 1570-80 (2010) (codified as amended in scattered sections of 15 U.S.C. (Supp. 2007-2011)).

9. See Dodd-Frank Wall Street Reform and Consumer Protection Act §§ 201217, 12 U.S.C. $\S \S 5381-5394$ (Supp. IV 2010) (naming the subchapter "Orderly Liquidation Authority”); DG WORKING DocumENT, supra note 8, at 51. The resolution regime would allow the important divisions of a bank to be separated out, continue business with minimal input, or be moved into healthy banks. Bad bank loans in one department would be isolated from the rest of the institution while the other "healthy" divisions of a bank would receive new capital to allow them to run normally. See id.; FIN. Stability Bd., Reducing the Moral HazARd Posed by Systemically IMPORTANT FinANCIAL INSTITUTIONS: FSB RECOMMENDATIONS AND TIME Lines 1-2 (2010), available at http://www.financialstabilityboard.org/publications/r_101111a.pdf. The FSB recommends various changes to resolve interconnected financial institutions in an orderly manner without costing taxpayers and while maintaining vital functioning. The recommended changes include subjecting the institutions to intensive supervision and resolution planning. See id.

10. See Steve Strongin et al., Goldman Sachs Global Mkts. Inst., Ending “ToO BIG To FAIL” 3-4 (2009), available at http://www2.goldmansachs.com/our-thinking/ public-policy/regulatory-reform/effect-reform-part-5.pdf (showing what could have happened if contingent capital had been in place during the recent economic crisis); DG WORKING DOCUMENT, supra note 8, Annex I, at 86-87.

11. For purposes of this Article, the terms contingent capital and contingent capital securities (CCS) will be used. There are other names for the same concept, such as contingent convertibles (CoCos). See Contingent Captital: CoCo Nuts, EcONOMIST, Nov. 5, 2009, available at http://www.economist.com/node/14816673?story_id=14816673. Another name for the concept is regulatory hybrid securities. See SQUAM LAKE WORKING GRP. ON FIN. REGULATION, AN EXPEDITED RESOLUTION MECHANISM FOR DISTRESSED FINANCIAL FIRMS: Regulatory HyBrid SeCURITIES 4 (2009), available at http://www.cfr.org/ economics/expedited-resolution-mechanism-distressed-financial-firms-regulatory-hybridsecurities/p19002 (suggesting that hybrid securities would increase creditors' 
proposals are expected to make financial institutions more resilient and avoid a future financial crisis. ${ }^{12}$ Although debt-equity conversion is not a new concept, ${ }^{13}$ the financial crisis has drawn increasing attention to this concept ${ }^{14}$ because conversion of debt into equity is seen as an

confidence in banks, prevent bailouts, and enable banks to raise more private capital). Squam Lake's suggested trigger mechanism would be dual: (1) “a declaration by regulators that the financial system is suffering from a systemic crisis. . . . [and (2)] a violation by the bank of covenants in the hybrid-security contract." Id. The bankspecific trigger would likely "be based on the measures used to determine a bank's capital adequacy, such as the ratio of Tier 1 capital to risk-adjusted assets." Id. Squam Lake also offers alternatives for the rate at which debt will convert to equity, including basing the conversion rate solely on market value of equity or on the market value of equity and the hybrid security. Id.; see also Mark J. Flannery, Stabilizing Large Financial Institutions with Contingent Capital Certificates 2-8, 11 (Ctr. for Applied Research in Fin., Working Paper No. 04/10, 2009), available at http://papers.ssrn. com/sol3/papers.cfm?abstract_id=1485689 (suggesting that firms would not be required to issue contingent capital certificates (CCC), but they could be used to reduce the equity capital they are required to hold). The conversion trigger should be "expressed in terms of equity's contemporaneous market value" and based on the firm's condition rather than the financial system as a whole. Id. at 2-3. Based on the structure of the CCC, "shareholders bear more of the downside outcomes resulting from their investment decisions." Id. at 5. Contingent capital certificates should be tax deductible for the firm. The author's example triggers when the common shares' market value falls below four percent of total assets. Id. at 7 . The conversion must occur rapidly, automatically, and enough CCC will convert to raise the percentage to five percent-or the required level. See id. at 7-8. Also, converted CCC must be replaced in the capital structure promptly. Id. at 7 . There are three possibilities for how to select which CCC would convert: (1) convert the shortest remaining maturity bonds first, (2) sell CCC with varying "seniorities" so some must convert fully before others begin to convert, or (3) select randomly. Contingent capital certificates are meant to reassign risk away from taxpayers and toward shareholders.

12. See, for example, Ceyla Pazarbasioglu et al., Int'l Monetary Fund, CONTINGENT CAPITAL: ECONOMIC RATIONALE AND DESign FEATURES: STAFF DisCussion NOTE 4 (2011), available at http://www.imf.org/external/pubs/ft/sdn/2011/sdn1101.pdf, for analysis on the merits of contingent capital as a crisis prevention tool based on the proposals by the Basel Committee, the FSB, and the EU.

13. See Karl Clowry, Debt-for-Equity Swaps, in RESTRUCTURING AND WorkOUTS: StrategIES FOR MAXIMISING VALUE 27, 30 (2008); Michael W. Elliott, Contingent Capital Arrangements, 18 Risk Mgmt. SEC. Q., Sept. 2001, at 1, 1-2, available at http://www. cpcusociety.org/file_depot/0-10000000/0-10000/3267/folder/20246/RMQsept.2001.pdf.

14. See Edmund L. Andrews, Bernanke, in a Bow to Critics of Fed's Role, Supports Forming a Regulatory Group, N.Y. TIMES, Oct. 2, 2009, at B3; Kristina Cooke, Fed's Rosengren Endorses Contingent Capital Idea, REUTERS, Mar. 3, 2010, http:// www.reuters.com/article/2010/03/03/usa-fed-rosengren-contingent-idUSWAT0141832 0100303; Damian Paletta, Officials Push 'Contingent Capital' for Banks, WALL ST. J., Oct. 22, 2009, at C7; William C. Dudley, President, Fed. Reserve Bank of N.Y., Remarks at the Reserve Bank of Australia's 50th Anniversary Symposium: The U.S. Financial System-Where We Have Been, Where We Are and Where We Need To Go 1 (Feb. 8, 2010), available at http://www.bis.org/review/r100211b.pdf?frames=0; Alan 
alternative to forcing strained, but not insolvent, financial institutions into liquidation. ${ }^{15}$

Professors Michael Bradley, Michael Rosenzweig, and others proposed the idea of using contingent capital in the context of corporate reorganization ${ }^{16}$ in the late 1980 s and early 1990s. ${ }^{17}$ Also known as "chameleon equity," 18 Bradley and Rosenzweig proposed to replace Chapter 11 with contingent capital providing for the automatic cancellation of a corporation's stock in the event of any default. ${ }^{19}$ The background of these early proposals can be compared and is rather close to today's sentiment in relation to public bailouts of large financial institutions. In the late 1980s and 1990s, executive compensation as well as executive bonuses and their lifestyles had been blamed for the bankruptcies of prominent companies such as Eastern Airlines ${ }^{20}$ and TWA, ${ }^{21}$ among

Greenspan, Chairman, Fed. Reserve, Subprime Lending and Securitization and Government-Sponsored Enterprises (GSOs), Testimony Before the Financial Crisis Inquiry Commission 11 (Apr. 7, 2010), available at http://cybercemetery.unt.edu/ archive/ fcic/20110310180041/http://c0182412.cdn1.cloudfiles.rackspacecloud.com/2010-0407Greenspan.pdf; Charles I. Plosser, President \& Chief Exec. Officer, Fed. Reserve Bank of Phila., Welcoming Remarks: Financial Interdependence in the World's Post-Crisis Capital Markets 4-5 (Mar. 3, 2010), available at http://www.philadelphiafed.org/ publications/speeches/plosser/2010/03-03-10_gic-philadelphia.pdf.

15. See John C. Coffee, Jr., Systemic Risk After Dodd-Frank: Contingent Capital and the Need for Regulatory Strategies Beyond Oversight, 111 CoLUM. L. REV. 795, 806, 825 (2011) (promoting contingent capital as an alternative to bankruptcy or bailouts, Coffee suggests a contingent capital design where "(1) [t]he conversion ratio would be deliberately designed to protect the debt holders from loss by instead diluting the existing equity holders, and (2) the debt security would convert into a fixed return preferred stock with cumulative arrearages and significant voting rights"). Coffee avers that converting the debt security into preferred stock creates a "countervailing voting constituency," which offsets the voting power of "risk-tolerant common shareholders, thereby reducing the pressure on corporate managers to accept greater risk and leverage.” Id. at 806. Under Coffee's proposal, conversion would be triggered when the common stock price significantly decreases. $I d$. at 836.

16. See Douglas G. Baird, A World Without Bankruptcy, 50 LAW \& ConTEMP. PROBS. 173, 182 (1987); Robert E. Scott, Through Bankruptcy with the Creditors' Bargain Heuristic, 53 U. CHI. L. REV. 690, 704-05 (1986).

17. See Barry E. Adler, Financial and Political Theories of American Corporate Bankruptcy, 45 StAn. L. REV. 311 (1993); Michael Bradley \& Michael Rosenzweig, The Untenable Case for Chapter 11, 101 YALE L.J. 1043 (1992). But see Lynn M. LoPucki, Strange Visions in a Strange World: A Reply to Professors Bradley and Rosenzweig, 91 Mich. L. REV. 79 (1992); Elizabeth Warren, The Untenable Case for Repeal of Chapter 11, 102 Yale L.J. 437 (1992); Martin J. Whitman et al., A Rejoinder to "The Untenable Case for Chapter 11,” 2 J. BANKR. L. \& PRAC. 839 (1993).

18. Adler, supra note 17, at 323; see also David A. Skeel, Jr., Markets, Courts, and the Brave New World of Bankruptcy Theory, 1993 WIS. L. REV. 465, 483 (1993).

19. Bradley \& Rosenzweig, supra note 17, at 1078.

20. John Greenwald, The Bankruptcy Game, Time, May 18, 1992, at 60.

21. Id. 
others. $^{22}$ Today, management and shareholders are blamed for the failure of A.I.G. and other recipients of bailout money. ${ }^{23}$

Although some suggest bankruptcy reform to remedy proprietary trading of banks and derivative trading, ${ }^{24}$ we do not suggest that Chapter 11 needs replacement. Rather, contingent capital can help stabilize large financial firms for which a Chapter 11 reorganization is not the ideal solution or not an option. The latter is specifically important when discussing contingent capital from the European perspective. In Europe, the prevailing perception seems to be that any financial institution filing for bankruptcy protection cannot be reorganized. ${ }^{25}$ In the United States, the Dodd-Frank Wall Street Reform and Consumer Protection (DoddFrank) Act does not focus on the reorganization of financial institutions as a going concern but favors orderly liquidation and wind-down. ${ }^{26}$ The use of contingent capital may provide a pre-liquidation reorganization procedure allowing a bank to be managed as a going concern with the option of staying in the market place and returning to profitability. But the utilization of contingent capital may provide additional benefits. For example, contingent capital may support the minimization of moral hazard ${ }^{27}$ and the avoidance of financial contagion, ${ }^{28}$ and limit systemic risk in the financial system that would otherwise be generated by financial institutions

22. See generally Laurence H. Kallen, Corporate Welfare: The MEGABANKRUPTCIES OF THE 80s AND 90s (1991) (explaining the relationship between corporate bankruptcies and Chapter 11 in the 1980s and 1990s).

23. See Edmund L. Andrews \& Peter Baker, At A.I.G., Huge Bonuses After \$170 Billion Bailout, N.Y. TIMES, Mar. 15, 2009, at A1.

24. See SKEEL, supra note 3, at 158.

25. Reinhard Bork, Grundfragen des Restrukturierungsrechts: Prolegomena zu einter Reform des deutschen Insolvenzrechts, 2010 ZEITSCHRIFT FÜR WIRTSCHAFTSRECHT UND InsolvenZPRAXIS 397 (no. 9) (2010); Yvonne Stengel, Das KreditinstituteReorganisationsgesetz: Rechtliche Aspekte der zukünftigen Sanierung und Reorganisation von Kreditinstituten, DER BETRIEB, Apr. 1, 2011 (Supplement), at 12; Lars Westpfahl, Vorensolvenzliches Sanierungsverfahren, 39 ZEITSCHRIFT FÜR UNTERNEHMENSUND GESELLSCHAFTSRECHT 385, 392 (2010).

26. Dodd-Frank Wall Street Reform and Consumer Protection Act § 214, 12 U.S.C. § 5394 (Supp. IV 2010). Section 5393 is the so-called Boxer Amendment. "All financial companies put into receivership under this subchapter shall be liquidated. No taxpayer funds shall be used to prevent the liquidation of any financial company under this subchapter." Id.; see also SKEEL, supra note 3, at 138 (noting that "the framework is designed with liquidation in mind").

27. See Coffee, supra note 15 , at $809-10$ (suggesting that converting debt into equity would effectively offset the pressure on managers to make risky investments, thereby reducing moral hazard).

28. Id. at 822 . 
that may be too big to fail. ${ }^{29}$ Contingent capital may also support general risk control in financial institutions, ${ }^{30}$ and in comparison with bankruptcy, the holders of contingent capital and former creditors could become active participants in the reorganization of the financial institution at a much earlier stage. Contingent capital is also less expensive and less time consuming and may set the right level of incentives by creating ownership stakes in its holders. Contingent capital could also be cheaper than equity financing if the interest expense is deemed tax deductible and if, in its non-dilutive form of financing, there is no threat of change of control associated with it.

A draft by the EU Commission, proposing a targeted and comprehensive approach to restructure and resolve financial institutions, ${ }^{31}$ recommends the mandatory issuance of contingent capital securities (CCS) for systemically important banks. ${ }^{32}$ The proposal suggests financial institutions could be required to issue CCS in volumes between four and nineteen percent of risk-weighted assets. ${ }^{33}$ European countries including Germany, England, and Switzerland and the Basel Committee have proposed rules

29. Goldman Sachs Global Mkts. Inst., Contingent Capital: Possibilities, PROBLEMS AND OpPORTUNITIES 3 (2011), http://www2.goldmansachs.com/our-thinking/ public-policy/regulatory-reform/contingent-capital.pdf ("At its core, contingent capital is simply a security that recapitalizes a troubled financial firm. It does so without recourse to taxpayer funds, which is why it is seen as such a promising solution to the too big to fail problem.”).

30. See Raghuram G. Rajan, Note to Douglas V. Diamond \& Raghuram G. Rajan, Fear of Fire Sales and the Credit Freeze 25, 28 (Bank for Int'l Settlements, Working Paper No. 305, 2010), available at http://www.bis.org/publ/work305.pdf (“[C]ontingent capital is like installing sprinklers .... [W] [Wen the fire threatens, the sprinklers will turn on.”). But see Christian Koziol \& Jochen Lawrenz, Contingent Convertibles: Solving or Seeding the Next Banking Crisis?, 36 J. BANKING \& Fin. 90, 91, 101 (2012) (suggesting that CoCo bonds may "create negative externalities, in the sense that the (destabilizing) risk-shifting problem induced by CoCo bonds may overcompensate the (stabilizing) effect of providing a pre-committed recapitalization to banks" and through the use of a "dynamic continuous-time framework" concluding that "the beneficial impact of CoCo bonds crucially hinges on the assumption if bank managers have substantial discretion over the bank's business risk"). Koziol and Lawrenz contend that if complete contracts can be written, CoCos are clearly beneficial; however, if allowing for incomplete contracts, the authors argue that "CoCo bonds always distort risk taking incentives." Id. at 101 . "Therefore, equity holders have incentives to take excessive risks. . . . Thus, CoCos may be an example where individually rational decisions can have systemically undesirable outcomes." Id.

31. See DG Working DocumEnT, supra note 8, Annex I, at 87-90.

32. See id. at 32, 87 (recognizing that contingent capital will likely be most useful with systemically important banks, but considering applying the resolution to all credit institutions).

33. Id. at 89 n.24. Other estimates for mandatory issuance of contingent capital range from four to eight percent of risk-weighted assets. See, e.g., GoldMAN SACHS GLOBAL MKTS. INST., supra note 29, at 13. 
on contingent capital. ${ }^{34}$ Similarly, the Dodd-Frank Act, in section 115(c), mandates a study on the feasibility of contingent capital. ${ }^{35}$ The study is due by July $2012 .^{36}$

With the implementation of mandatory contingent capital rules, the EU Commission and the U.S. Congress may be mandating the establishment of a new market in CCS. It is unclear how and when a market in CCS could gain critical mass, ${ }^{37}$ what volumes in CCS will be issued by financial institutions, how rating agencies may rate CCS, what long-term implications and possible applications CCS could have, ${ }^{38}$ and whether CCS will be listed in benchmark indices. The market acceptance

34. See BASEl Comm. On BANKING SuPERVISION, BANK FOR INT’L SETTLEMENTS, BASEL III: A GLOBAL REGULATORY FRAMEWORK FOR MORE RESILIENT BANKS AND BANKING SYSTEMS 1, 7 (2010), available at http://www.bis.org/publ/bcbs189_dec2010.pdf (addressing systemic risk and interconnectedness and developing approaches including contingent capital and bail-in debt); STATE SEC. FOR INT’L FIN. MATTERS OF THE SwISS CONFEDERATION, FINAL REPORT OF THE COMMISSION OF EXPERTS FOR LIMITING THE ECONOMIC RISKS Posed By LARge COMPANIES 4, 59-60 (2010) [hereinafter SwISS REPORT], available at http://www.sif.admin.ch/dokumentation/00514/00519/00592/index.html?lang=en (showing that part of the Swiss proposal to deal with systemically important institutions is to apportion nine percent of the total capital ratio in contingent convertible bonds with predefined triggers); BANK OF ENG., FINANCIAL STABILITY REPORT 56 (2010), available at http://www.bankofengland.co.uk/publications/fsr/2010/fsrfull1012.pdf (suggesting that contingent capital will result in higher loss absorbency and proposing two types of contingent capital: precautionary and non-viability); BUNDESMINISTERIUMS DER JUSTIZ, GESETZ ZUR ÄNDERUNG DEs AKTIENGESETZES, BEARBEITUngsstand: ReFERENTENENTWURF 17-18 (2010), available at http://www.der-betrieb.de/content/pdfft,0,395158.

35. Dodd-Frank Wall Street Reform and Consumer Protection Act §§ 115(c), 165(b), 12 U.S.C. §§ 5325(c), 5365(b) (Supp. IV 2010).

36. Id. $\S 115(\mathrm{c})(2)$ ("The Council shall submit a report to Congress regarding the study required by paragraph (1) [contingent capital study required] not later than 2 years after the date of enactment of this Act [July 21, 2010].”).

37. See Wulf A. Kaal, Initial Reflections on the Possible Application of Contingent Capital in Corporate Governance, 26 NOTRE DAME J.L. ETHICS \& PUB. POL'Y 101, 13538 (2012).

38. Id. at 101 ("The regulatory evaluation of contingent capital in the United States could be an opportunity to assess the possible application of contingent capital in the corporate governance of SIFIs. While regulatory initiatives in Europe and the academic debate in the United States are dominated by efforts to improve the technical design features of contingent capital securities, ... contingent capital designs in various jurisdictions could benefit from experimentation and a learning experience that takes corporate governance applications into account. As the design features evolve and their scope and impact become clearer, possible corporate governance improvements could become more obvious."). For a further evaluation of the possible applications of contingent capital in corporate governance and specifically in executive compensation, see Wulf A. Kaal, Contingent Capital in Executive Compensation (unpublished manuscript) (on file with author). 
may depend to a significant extent on the design features of CCS and ratings by rating agencies.

Crucial for the effectiveness and impact of contingent capital, and therefore most contentious among scholars and policymakers, is the design of the triggering event. ${ }^{39}$ If conversion of CCS from debt into equity is triggered too early without a real financial need for an equity capital injection and additional voting shareholders, the expected financial impact of the equity capital injection may dissipate. If triggered too early, the capital injection may no longer be available when actually needed to avoid resolution. On the other hand, if conversion from debt to equity is triggered too late, the financial institution may already be in the resolution stage, and conversion at that stage may not supply the company with sufficient equity to facilitate the desired financial improvement.

Given the risk that policymakers could structure contingent capital rules with a suboptimal trigger design combined with the multiple benefits of using contingent capital in different phases of a company's life cycle, this Article suggests a sequential trigger design for CCS. Although the first trigger may follow a design that has previously been suggested by

39. See Robert L. McDonald, Contingent Capital with a Dual Price Trigger 1, 20 (Apr. 11, 2011) (unpublished manuscript), available at http://ssrn.com/abstract $=1553430$ (proposing a model for contingent capital where debt converts to equity if both (1) "the firm's stock price is at or below a trigger value," and (2) "the value of a financial institution's index is also at or below a trigger value”). McDonald concludes that the dual trigger proposal's strength is its reliance on market prices, and its disadvantage is the index trigger, which could potentially create a situation where "bondholders could have an incentive to try to force the institution into bankruptcy before conversion can occur." Id. at 13; see also George Pennacchi et al., Contingent Capital: The Case for COERCs 9, 13 (Oct. 2010) (unpublished manuscript), available at http://papers.ssrn. com/sol3/papers.cfm?abstract_id=1656994 (proposing a call option enhanced reversed convertible (COERC) security as a form of contingent capital). A COERC has two significant features: (1) "the conversion price is set significantly below the trigger price," and (2) shareholders have the option to "buy the shares back from the bondholders after conversion at this same low conversion price." Id. at 9. Pennacchi notes that for conversion to occur at such low stock prices, common stock holders would have to approve the increase in authorized shares. Id. The authors assert that the structure of COERCs would potentially make future financial distress less likely, stating that "the fact that the conversion price is set significantly below the trigger price gives a strong incentive for shareholders to ... repay the bonds at their par value. This will in turn reduce the risk of the bonds, thereby enhancing their marketability with fixed income investors.” Id.; see also Suresh M. Sundaresan \& Zhenyu Wang, On the Design of Contingent Capital with Market Trigger 6, 10 (Fed. Reserve Bd. of N.Y., Working Paper Series Staff Report No. 448, 2011), available at http://papers.ssrn.com/sol3/papers.cfm?abstract_id=1612894 (recognizing that a value transfer between equity and contingent capital "disturbs equilibrium by moving the stock price up or down depending on the conversion ratio," and that the proposals typically ensure that there is no value transfer at maturity but do not ensure there is no transfer before maturity). 
other authors, ${ }^{40}$ we suggest a second trigger of contingent capital before the resolution of a financial institution but after conversion into equity. Increasing the voting rights pre-resolution could be triggered by evidence that the conversion into equity was not successful, that conversion was triggered too early or too late, or that there is an overall continuing downward trend in the financial performance of the company. ${ }^{41}$ This could provide additional incentives for shareholders and management to avoid further dilution. The second trigger design could also signal a further potential increase in default risk. The holders of contingent capital, whose debt securities would have converted into equity securities at that point, would receive increased voting rights if the financial situation of the institution did not improve after conversion into equity. Only prior contingent capital holders would receive increased voting rights, provided the financial situation of the institution did not improve sufficiently after conversion into equity but before authorities initiated liquidation and the transfer of assets. Besides providing for super-voting rights and increasing dilution, the second trigger would also be a reorganization tool independent of management decisions or corrective action by regulators. The second trigger could also increase the marketability of CCS and may allow rating agencies to adequately assess this form of convertible securities.

This Article's proposal would add another dimension to the draft of the EU Commission by integrating contingent capital in the early prevention phase in addition to the resolution phase, as suggested by the Commission. ${ }^{42}$ Assuming a predefined mandatory issuance of CCS under EU law, ${ }^{43}$ sequential triggers within the EU Commission's targeted and comprehensive approach $^{44}$ could take various forms. Although we appreciate the need for optimal design features of the first trigger that converts contingent capital into equity, the focus of this Article will be on the potential design

40. See, e.g., McDonald, supra note 39, at 2 (suggesting conversion when the firm's stock price falls and the value of the firm falls below a trigger price); Pennacchi et al., supra note 39, at 14 (suggesting a conversion price below a specified trigger).

41. We recognize the risk that the market may interpret the actual triggering of the first trigger negatively. The determination of inadequacy of the first trigger or a continuing financial weakening may depend on multiple factors. We recognize the need for carefully calibrated criteria assessing financial weakening after the first trigger.

42. See DG WORKING DocumENT, supra note 8, Annex I, at 87-89.

43. See id. at $89 \&$ n.24 (suggesting a minimum mandatory issuance of contingent capital between four and nineteen percent of risk-weighted assets).

44. See id. at 87-89. 
of a second trigger before resolution. ${ }^{45}$ Although we do not intend to take sides in the debate on an optimal design of the first trigger, we are inclined to favor a threshold in market value as a basis for a trigger design. $^{46}$ The volume of CCS issuance should probably be large enough to result in sufficient dilution upon conversion, ${ }^{47}$ and the timeframe for the trigger should probably be around ninety days. ${ }^{48}$ The herein-suggested design of the first trigger leaves many questions unanswered.

In the United States, the Dodd-Frank Act mandates orderly liquidation. ${ }^{49}$ The Federal Deposit Insurance Corporation (FDIC) is drafting rules requiring the biggest financial firms to plan for orderly liquidations should they face collapse. ${ }^{50}$ U.S. policymakers could benefit from considering contingent capital as a preventive tool as well as a tool before resolution of a financial institution. Using a second trigger to increase voting rights of contingent capital holders before resolution could work equally well in the United States and the European regulatory schemes. The interplay of conversion from debt to equity before resolution as a preventive act and the second trigger of contingent capital before resolution in the European and U.S. legal frameworks would need to be carefully calibrated.

Additional research will be needed to adequately evaluate the interplay of the first and second trigger and the incentive structure for contingent

45. Our Article builds on the research on the efficient design of first triggers by Coffee, supra note 15; Flannery, supra note 11; McDonald, supra note 39, at 1; George Pennacchi, A Structural Model of Contingent Bank Capital (Fed. Reserve Bank of Cleveland, Working Paper No. 10-04, 2010), available at http://papers.ssrn.com/sol3/ papers.cfm?abstract_id=1595080.

46. The core argument for this design feature is that it helps avoid total reliance on accounting methods that could otherwise be subject to manipulation. A promising approach suggested by Calomiris and Herring focuses on the quasi-market value of equity ratio. See Charles W. Calomiris \& Richard J. Herring, Why and how To Design a Contingent Convertible Debt Requirement 1 (Nov. 2011) (unpublished manuscript) (on file with University of Pennsylvania), available at http://fic.wharton.upenn.edu/fic/papers/11/1141.pdf (proposing a contingent capital requirement both to prevent bailouts and as an incentive to capitalize and suggesting that for a contingent capital requirement to be most effective: "(a) a large amount of CoCos (relative to common equity) should be required, (b) CoCo conversion should be based on a market value trigger, defined using a moving average of a 'quasi market value of equity ratio' (QMVER), (c) all CoCos should convert if conversion is triggered, and (d) the conversion ratio should be dilutive of preexisting equity holders").

47. See StRONGIN ET AL., supra note 10, at 5.

48. See id. at 6 (suggesting a period of thirty days after triggering during which firms could recapitalize in public markets, and that if the firm is unable to recapitalize, the capital would convert automatically).

49. Dodd-Frank Wall Street Reform and Consumer Protection Act § 204, U.S.C. $\S 5384$ (Supp. IV 2010) (titling the section "Orderly liquidation of covered financial companies”).

50. See Eric Dash, Chairwoman at F.D.I.C. Is Departing, N.Y. Times, May 10, 2011, at B1. 
capital holders, shareholders, and management. ${ }^{51}$ This Article evaluates regulatory proposals on restructuring of financial institutions and the role contingent capital may play in this context. We point out the pertinent issues that need to be resolved before regulatory proposals can be implemented in Europe and the United States and suggest a solution to some of the open issues by providing a comparative perspective on contingent capital and the use of a second trigger before resolution. We also describe where additional research may be needed and what additional steps could be taken to further optimize the use of contingent capital in bank restructuring.

\section{CONTINGENT CAPITAL}

For purposes of this Article, contingent capital is the predefined conversion of a certain percentage of financial institutions' debt securities into equity securities. ${ }^{52}$ A common denominator in the proposals on the use of contingent capital in the context of avoiding future crises could be the issuance of a certain percentage of a financial institution's long-term debt capital as convertible debt securities that convert into equity when triggered by financial weakening of the financial institution. ${ }^{53}$

51. The role of this Article is to point out the benefits of contingent capital not only as a preventive tool but also in reorganization. We appreciate that the calibration of first and second trigger designs will require a learning experience and a concerted effort of regulators worldwide.

52. For purposes of this Article, the terms contingent capital and CCS will be used. Other terms for the same concept are: CoCos, regulatory hybrid securities, contingent capital certificates, or embedded contingent capital. Julie Dickson, Superintendent, Office of the Superintendent of Fin. Insts. Can., Remarks at the Financial Services Invitational Forum 4 (May 6, 2010), available at http://www.osfibsif.gc.ca/app/DocRepository/1/ eng/speeches/jdlh20100506_e.pdf.

53. See Coffee, supra note 15, at 805; McDonald, supra note 39, at 20; Flannery, supra note 11, at 2, 12; Darrell Duffie, Contractual Methods for Out-of-Court Restructuring of Systemically Important Financial Institutions (Dec. 9, 2009) (unpublished manuscript), available at http://media.hoover.org/sites/default/files/documents/06Ending GovernmentBailoutsAsWeKnowThemDuffie.pdf (focusing on possible triggers of distress-contingent convertible bonds/debt-essentially CCS). Duffie suggests that if the trigger is an accounting capital ratio, it may not be able to capture the true financial condition of the bank because of accounting failures. See id. The ratio of tangible common equity to tangible assets may be more effective because it excludes the relatively "useless assets during a solvency crisis." Id. at 4 . If the trigger is determined by market value, the impact of a short seller speculative attack could be mitigated by using a trailing average share price, for example, the preceding twenty days. To eliminate a "bank run," the trigger should be set to convert debt into equity before a liquidity crisis begins. Id. at 5. Duffie also discusses mandatory rights offerings. Id. at 6-8. 
However, debt-equity conversion is not a new concept. ${ }^{54}$ The financial crisis has drawn increasing attention to this concept because the conversion of debt into equity could be an attractive alternative to forcing strained, but not insolvent, financial institutions into restructuring or liquidation. ${ }^{55}$

\section{A. Potential for Reform and Financial Stability}

Contingent capital securities will likely play a major role in attempts by various jurisdictions at providing rules that would allow the efficient restructuring and resolution of failing financial institutions. ${ }^{56}$ Policymakers in the United States and the European Union support the idea of implementing contingent capital. ${ }^{57}$ Because contingent capital is perceived as stabilizing systemically important financial institutions (SIFIs) and preparing them for future financial crises, ${ }^{58}$ several academics also support the concept of contingent capital. ${ }^{59}$

Although the scope and role of contingent capital is contentious, ${ }^{60}$ there seems to be some consensus on the core objectives that may be achieved by

54. See Clowry, supra note 13, at 27-28; Elliott, supra note 13. "Pfandbriefe" or covered bonds, created in 1769 in Prussia, became the blueprint for the covered bond models in Europe and beyond. See Ted Lord, The Investor's Perspective, in COVERED BONDS AND PFANDBRIEFE: InNOVATIONS, InVESTMENT AND STRUCTURED Alternatives 60, 62-63 (Jonathan Golin ed., 2006).

55. See Coffee, supra note 15, at 816, 825.

56. See DG WORKING Document, supra note 8, Annex I.

57. See Christoph K. Henkel \& Wulf A. Kaal, Contingent Capital in European Union Bank Restructuring, N.W. J. INT'L L. \& BUS. (forthcoming 2012) (on file with authors); Andrews, supra note 14 (quoting Bernanke stating "that giant financial players might be forced to adopt 'contingent' capital," and noting that contingent capital is "gaining popularity within the Fed"); Daniel K. Tarullo, Governor, Fed. Reserve, Speech at the Exchequer Club in Washington, D.C., to the Federal Reserve: Confronting Too Big To Fail (Oct. 21, 2009) (transcript available at http://www.federalreserve.gov/ newsevents/speech/tarullo20091021a.htm) (commenting that contingent capital is an effort “worth pursuing”); Press Release, European Commission, Commission Wants Stronger and More Responsible Banks in Europe (July 20, 2011), available at http:// europa.eu/rapid/pressReleasesAction.do?reference $=\mathrm{IP} / 11 / 915 \&$ format $=$ HTML\&aged $=0$ \&language=en\&guiLanguage=en ("The proposal will require banks to hold more and better capital to resist future shocks by themselves.”). The proposal also translates the bank capital agreed to in the Basel III agreement. See also SwISS REPORT, supra note 34, at 41-42 (proposing the conversion of contingent capital upon certain triggering events).

58. See Flannery, supra note 11, at 2.

59. See, e.g., SKEEL, supra note 3, at 84 (referring to contingent capital as a "promising strategy"); Coffee, supra note 15, at 801-03 (promoting contingent capital as an alternative to bailouts); Henkel \& Kaal, supra note 57; Pennacchi et al., supra note 39, at 1 (noting that contingent capital can prevent bailouts of banks that are "too big to fail”).

60. See, e.g., SKEEL, supra note 3, at 84-85 (pointing out that contingent capital will not likely be effective if a bank can "easily manipulate its capital," and that contingent capital "will not protect against a sudden collapse, as in the cases of Bear Stearns and AIG”); Koziol \& Lawrenz, supra note 30, at 91, 101 (suggesting that CoCo bonds may "create negative externalities, in the sense that the (destabilizing) risk-shifting problem 
implementing contingent capital proposals. Among those are the objectives of bail-in, ${ }^{61}$ signaling default risk, ${ }^{62}$ incentive to increase capital, ${ }^{63}$ and less risk-taking. ${ }^{64}$

Benefits of implementing contingent capital into national regulatory frameworks could include the minimization of moral hazard, ${ }^{65}$ avoidance of financial contagion, ${ }^{66}$ and limitation of systemic risk in the financial system that would otherwise be generated by SIFIs that are too big to

induced by CoCo bonds may overcompensate the (stabilizing) effect of providing a precommitted recapitalization to banks" and through the use of a "dynamic continuous-time framework" concluding that "the beneficial impact of CoCo bonds crucially hinges on the assumption if bank managers have substantial discretion over the bank's business risk”); Oliver Hart \& Luigi Zingales, A New Capital Regulation for Large Financial Institutions 5-7 (Fondazione Eni Enrico Mattei, Working Paper No. 124.2009, 2009), available at http://papers.ssrn.com/sol3/papers.cfm?abstract_id=153 3274. In proposing a market-based trigger, the authors point out that Flannery's 2005 proposal has three potential shortcomings: "First, it is too lenient toward management, eliminating one of the disciplinary effects of debt. Second, it can have perverse effects: the manager talking down the stock so as to obtain more slack. Third, it generates multiple equilibria, some of which are inefficient." Id. at 5.

61. See Coffee, supra note 15, at 801-03 (promoting contingent capital as an alternative to bailouts); SQUAM LAKE WORKING GRP. ON FIN. REGULATION, supra note 11, at 3-4 (suggesting that hybrid securities would help prevent bailouts); Calomiris \& Herring, supra note 46, at 39 (averring that contingent capital could help prevent the "too big to fail" problem).

62. See William C. Dudley, President \& Chief Exec. Officer, Fed. Reserve of N.Y., Remarks at the Institute of International Bankers Membership Luncheon: Some Lessons from the Crisis 4, 6-7 (Oct. 13, 2009) (transcript available at http://www.bis. org/review/r091014a.pdf?frames=0) (proposing that CCS can be used to adequately capture risk); Raghuram Rajan, More Capital Will Not Stop the Next Crisis, FIN. TIMES (Eng.), Oct. 2, 2009, at 9 (suggesting that CCS should be used to raise capital "when regulators see a crisis coming”).

63. See SouAm LaKe Working Grp. On Fin. Regulation, supra note 11, at 4 (suggesting that contingent capital will enable banks to raise more capital); see also Calomiris \& Herring, supra note 46, at 39 (proposing that a contingent capital requirement would be an incentive to capitalize).

64. See Dudley, supra note 62, at 6 (averring that because of bank difficulties that would trigger conversion, this dilution of shareholders creates an incentive for bank managers to "manage not only for good outcomes on the upside of the boom, but also against bad outcomes on the downside"); Pennacchi et al., supra note 39, at 9, 13 (suggesting that their COERC proposal would reduce the risks of bonds).

65. Mark J. Flannery, No Pain, No Gain? Effecting Market Discipline via "Reverse Convertible Debentures” 15 (Nov. 2002) (unpublished manuscript), available at http:// papers.ssrn.com/sol3/papers.cfm?abstract_id=352762 ("Frequent trigger evaluations eliminate moral hazard incentives and expose the RCD to surprisingly low default risk.”).

66. See STRONGIN ET AL., supra note 10, at 6,10 (noting that if the appropriate triggers are in place, it could prevent bank runs - though if the trigger is based on market prices, it could worsen bank runs). 
fail. ${ }^{67}$ Contingent capital could also support general risk control in financial institutions. ${ }^{68}$ By internalizing bank failure costs, contingent capital may contribute to minimizing moral hazard. A contingent debt security with a conversion trigger would presumably not default and could thus help avoid contagion and systemic spillover effects, which in turn may limit systemic risk. Contingent capital is also an automatic mechanism for increasing capital while reducing debt with the long-term benefit of lowering leverage. ${ }^{69}$

CCS could also be used to adequately capture risk. CCS will likely be more efficient than raising capital requirements because the capital arrives only when it is needed. Contingent capital could incentivize principalsowners-managers to lower their risk-taking on behalf of the financial institution. $^{70}$ The threat of loss due to conversion of CCS and the implicit dilution of stock holdings could reduce incentives for shareholders to encourage management to take higher risks for higher returns. Dilution of shareholders creates an incentive for bank managers to "manage not only for good outcomes on the upside of the boom, but also against bad outcomes on the downside."71 Should conversion have a negative effect on the stock price, ${ }^{72}$ management could be further incentivized to maintain and manage risk to avoid reputational loss and income reduction due to losses in stock options. ${ }^{73}$ Some studies have shown that stricter controls,

67. See Coffee, supra note 15, at 806 (suggesting that contingent capital should be designed to create a standard for SIFIs).

68. See Diamond \& Rajan, supra note 30, at 28 (“[C]ontingent capital is like installing sprinklers. . . . [W] [Wen the fire threatens, the sprinklers will turn on.”). But see Koziol \& Lawrenz, supra note 30 , at $91,100-01$ ("[C]ontrary to the previous work on CoCo bonds, our results demonstrate that CoCo bonds can create negative externalities for the economy, and that individually rational decisions may have systemically undesirable outcomes.").

69. See Coffee, supra note 15, at 805 (averring that contingent capital can counter leverage debt).

70. See id. at 806 (averring that converting the debt security into preferred stock creates a "countervailing voting constituency," which offsets the voting power of "risktolerant common shareholders, thereby reducing the pressure on corporate managers to accept greater risk and leverage”); Dudley, supra note 62, at 6 (asserting that because of bank difficulties that would trigger conversion, this dilution of shareholders creates an incentive for bank managers to "manage not only for good outcomes on the upside of the boom, but also against bad outcomes on the downside").

71. Dudley, supra note 62, at 6.

72. A potential effect of CCS conversion on stock prices will likely be evaluated in future research. See Sundaresan \& Wang, supra note 39, at 21 (suggesting that under their design of contingent capital, where the state-contingent conversion ratio prevents value transfer, the prices would be kept “'smooth” at conversion”).

73. Even though there is a trend toward a reduction in stock option compensation, management may still receive a certain percentage of its compensation in stock options. See Guido Ferrarini \& Maria Cristina Ungureanu, Economics, Politics, and the International Principles for Sound Compensation Practices: An Analysis of Executive Pay at European Banks, 64 VAND. L. REV. 431, 460 (2011) (noting that stock option compensation has 
corporate governance constraints, and stronger regulatory pressure may incentivize financial institutions to act more prudently and to avoid excessive risk-taking. ${ }^{74}$ CCS may also have the potential for further enhancement of regulatory capital required by the Federal Reserve ${ }^{75}$ and Basel III. ${ }^{76}$ It could create a regime for providing countercyclical regulatory capital in an efficient way, ${ }^{77}$ while displaying both "stick" and "carrot" incentives. ${ }^{78}$ Swiss legislators have already implemented rules on enhancing the role of contingent capital as regulatory capital. ${ }^{79}$

\section{B. Limitations and Open Issues}

Despite the many benefits of contingent capital and its potential for helping to save financial firms, contingent capital cannot prevent economic

been curtailed; for example, in France, remuneration requirements ban stock options and limit bonuses).

74. See Tao-Hsien Dolly King \& Min-Ming Wen, Shareholder Governance, Bondholder Governance, and Managerial Risk-Taking, 35 J. BANKING \& FIN. 512, 530 (2011) (showing that strong bondholder governance incentivizes low-risk investments); Bertrand Rime, Capital Requirements and Bank Behaviour: Empirical Evidence for Switzerland, 25 J. BANKING \& Fin. 789, 803-04 (2001); Ronald E. Shrieves \& Drew Dahl, The Relationship Between Risk and Capital in Commercial Banks, 16 J. BANKING \& FIN. 439, 455-56 (1992).

75. The Fed requires another three percent for systemically important banks, bringing the total regulatory capital requirement to ten percent. Dodd-Frank Wall Street Reform and Consumer Protection Act § 171, 12 U.S.C. § 5371 (Supp. IV 2010) (requiring federal banking agencies to establish minimum capital requirements); John H. Cochrane, The More Bank Capital, the Safer the Bank, Wall ST. J., July 15, 2011, at A15. The Fed's Dan Tarullo even proposed fourteen percent. Id.

76. Basel III calls for seven percent regulatory capital, up from three percent. Press Release, Bank for Int'l Settlements, Group of Governors and Heads of Supervision Announces Higher Global Minimum Capital Standards 1-2 (Sept. 12, 2010), http:// www.bis.org/press/p100912.pdf.

77. Dudley, supra note 62, at 6-7.

78. Rajan, supra note 62 (suggesting that CCS should be used to raise capital "when regulators see a crisis coming," that raising capital through CCS during "good times" will allow it to be cheap and easier to enforce, and also that infusing capital during "bad times" protects the system and the taxpayers with the right contingencies in place). Contingent capital securities have both "stick" and "carrot" incentives. Automatic conversion of CCS has a disciplinary effect by punishing aggregate bank losses. Id. Conversion when a bank's capital ratio falls below a certain level encourages banks to anticipate losses, to raise new capital, and to protect the taxpayers and their shareholders. Id. But see Cochrane, supra note 75 (arguing that financial engineers will likely find a way to circumvent the new rules on regulatory capital under Basel III and Dodd-Frank because they did so successfully in the past, and that as long as the government subsidizes lending and bailouts, more capital is needed to make banks safer).

79. SWISS REPORT, supra note 34, at 59 tbl.4 (proposing six percent CoCos for regulatory capital in Switzerland). 
failure. $^{80}$ Contingent capital can only limitedly protect against information asymmetries, principal/agent issues, and collective action problems. ${ }^{81}$ Among the open issues of discontent are the objectives of CCS, ${ }^{82}$ CCS design features and their calibration, ${ }^{83}$ the mandatory or voluntary nature of contingent capital, ${ }^{84}$ the volume of CCS issuance, ${ }^{85}$ CCS market development, ${ }^{86}$ and others. ${ }^{87}$ In light of these limitations and open issues,

80. See Coffee, supra note 15, at 833 ("If a firm's variable costs clearly exceed its revenues, and no turnaround is in sight, the firm will not be saved by converting its bonds into preferred stock. . . . [and] resolution authority provides the superior mechanism for its liquidation. Thus, the boundaries within which contingent capital can feasibly work are set by the firm's ability to recover its variable costs.”).

81. For further discussion, see infra Part IV.B.

82. See SQUAM LAKE WORKING GRP. ON Fin. RegUlation, supra note 11 , at 4 (noting that contingent capital is intended to increase creditors' confidence in banks, prevent bailouts, and enable banks to raise more capital).

83. See Coffee, supra note 15, at 827 (noting that many papers focus on the mechanics of contingent capital); Meera Louis, Europeans Lose Out to U.S. with Basel Committee's Contingent Capital Vote, BloOMBERG (June 27, 2011), available at http://www.bloomberg.com/news/2011-06-26/basel-committee-decision-on-contingentcapital-backs-u-s-stance.html (commenting that not all European countries even support the use of contingent capital). Scholars have suggested a variety of different design features. See, e.g., Duffie, supra note 53, at 3 ("There are a number of alternative designs for the distress trigger and for the conversion ratio, the number of shares of equity to be received in exchange for each dollar of bond principal.”); Flannery, supra note 11, at 4 (arguing that "the conversion trigger must be expressed in terms of equity's contemporaneous market value”); McDonald, supra note 39, at 1-2.

84. See Mary Frances Monroe, Am. Bankers Ass'n, Response Submission Re: Consultative Document: Proposal To Ensure the Loss Absorbency of Regulatory CAPITAL AT THE POINT OF NON-VIABILITY 3 (2010) ("[Mandatory contingent capital] would hinder unduly the flexibility of banks to create a capital structure that best meets the needs of the bank and its investors. ... . Other banks may not be able to, or may find it inefficient to, issue contingent or convertible instruments for a variety of reasonsincluding, for instance, restrictions under their chartering instruments, tax issues related to the deductibility of payments on the instruments, lack of market access, or insufficient investor interest. These banks should not be harmed by a perception that they are not as well capitalized as others simply because they need to or choose to meet their capital needs through other acceptable channels.”); Coffee, supra note 15, at 808 (suggesting, in support of mandatory implementation of contingent capital, that "it can work even when regulatory oversight fails and a crisis sneaks in under the regulators' radar screen”).

85. See GOLDMAN SACHS GLOBAL MKTS. INST., supra note 29, at 20 app.D (estimating, in analyzing the sizing of a potential contingent capital market, that the "potential amount of contingent capital that might be issued starts with the Basel Committee's requirement that all non-common Tier 1 and 2 securities eventually have a loss-absorption feature”); STRONGIN ET AL., supra note 10, at 4 (suggesting that contingent capital holdings equivalent to six percent of risk-weighted assets would have been sufficient to have the firms recapitalize voluntarily instead of converting the contingent capital).

86. See Monroe, supra note 84, at 2 (expressing concern that the Basel Committee's proposal "would make contingent capital indistinguishable from common equity" and stating that "[t]he proposal would change fundamentally the risk-reward profiles of bank debt and equity investors, ultimately raising concerns about the marketability of these instruments”); EUROPEAN Ass'N OF PUBLIC BANKS, COMMENTS OF THE EUROPEAN ASSOCIATION OF PUBLIC BANKS ON THE CONSULTATION ON TECHNICAL DETAILS OF A POSSIBLE EUROPEAN CRISIS MANAGEMENT FRAMEWORK 8-9 (2011), available at http://www.eapb.eu/ 
policymakers will have to make critical decisions to resolve open design issues and overcome potential flaws in the design of contingent capital in their respective jurisdictions. Contingent capital may not directly address the underlying problems that triggered the credit crisis. Even though many factors were involved in triggering the crisis and often had knock-on effects on each other, information asymmetries and principal/agent problems may be at the core of the crisis. ${ }^{88}$

Although contingent capital has many beneficial attributes, existing proposals for implementing contingent capital are unclear as to how they will address information asymmetries and principal/agent problems. ${ }^{89}$ The issuance of contingent capital will likely involve many uncertainties.

file?fle=6701 (pointing out, with regard to the comprehensive approach, burdens including higher costs to the banks for senior debt instruments and the marketability of this type of instrument); EUROPEAN BANKING FED., POSITIONING IN RESPECT OF THE EU Commission Consultation on Technical Details for a Possible EU Framework FOR BANK RECOVERY AND RESOLUTION 56 (2011), available at http://www.ebf-fbe.eu/ uploads/documents/positions/BankingReg/3\%20March\%20201-EBF_Response_to_COM_ Crisis_Management_Consultation\%20\%28final\%29.pdf (pointing out, with regard to the targeted approach to contingent capital, that predictions examining the market acceptance of such securities simply do not exist).

87. Other issues that remain open and debated are the specific trigger mechanisms and whether the trigger is market-value or risk-asset based. See, e.g., EUROPEAN Ass'N OF PUBlic BANKS, supra note 86, at 8-9 (questioning, with regard to the targeted approach, how the appropriate issuance level and cost will be determined, and noting that a very limited group of investors will be interested in these instruments); Hart \& Zingales, supra note 60, at 5-7 (pointing out, in proposing a market-based trigger, that Flannery's 2005 proposal has three potential shortcomings: (1) "it is too lenient toward management, eliminating one of the disciplinary effects of debt"; (2) "it can have perverse effects: the manager talking down the stock so as to obtain more slack"; and (3) "it generates multiple equilibria, some of which are inefficient”); Stan Maes \& Wim Schoutens, Contingent Capital: An In-Depth Discussion 17 (Aug. 2, 2010) (unpublished manuscript), available at http://papers.ssrn.com/sol3/papers.cfm?abstract_id=1653877 (pointing out that contingent capital instruments "are very hard to value under a particular model"). Maes and Schoutens also suggest that the "extreme complexity" of CoCos may hamper their success. Id.

88. See Wulf A. Kaal, Hedge Fund Valuation: Retailization, Regulation, and Investor Suitability, 28 REV. BANKING \& FIN. L. 581, 624 (2008) ("The combination of various layers of principal-agent relationships, bounded rationality, moral hazard and incomplete and asymmetric allocation of information could have resulted in market failure for complex financial instruments.”). For a suggestion of a framework for "good corporate governance" taking into account the framework for economic rules and the knock-on effects between micro and macro levels, see Christian Kirchner, Corporate Governance und Ordnungsökonomik, 62 ORDO JAHRBUCH FÜR DIE ORDNUNG VON WIRTSCHAFT UND GESELLSCHAFT 321, 321-41 (2011).

89. A second trigger increasing voting rights could help minimize information asymmetries and principal/agent problems. See infra Part IV.B. 
For instance, the nature of contingent capital as a hybrid instrument is unclear. Contingent capital instruments would have fixed returns-as debt security-while displaying risk-bearing properties, similar to equity. ${ }^{90}$ As a hybrid security, contingent capital may receive low or no ratings and may have a much smaller investor base and higher costs of funding. The desirability of conversion features that turn a debt holder into an equity holder may also be questionable, ${ }^{91}$ and the uncertainty involved in buying CCS could deter investors. Even if a reliable trigger mechanism could be designed, the many outstanding trigger design issues could negatively affect the predictability of a conversion from debt into equity. ${ }^{92}$

If and how contingent capital will count toward banks' Tier 1 capital ratios is also unclear. Because agreeing on EU-wide standards may be nearly impossible, the newly created European Banking Authority (EBA) is likely to allow national regulators to use their existing Tier 1 definitions. ${ }^{93}$ This creates collective action problems. A country that uses stricter definitions of Tier 1 capital could appear to have less capital and thinner capital cushions than banks in countries with broader definitions for Tier 1 capital. For instance, in contrast to other regulators, the Financial Services Authority (FSA) in the United Kingdom uses a stricter definition of Tier 1 capital. ${ }^{94}$ Germany, among other countries, uses wider definitions for Tier 1 capital, ${ }^{95}$ which can result in higher capital ratios. In the context

90. See DG Working Document, supra note 8, Annex I, at 90 ("[The] higher cost of such instruments may simply reflect the view that risk has been transferred from society [taxpayers-moral hazard] to the bondholder by the removal of the implicit State guarantee for creditors that may have artificially reduced the costs of debt funding. This may in particular be the case for those institutions that have been considered 'too big to fail."”).

91. See id. (discussing the benefits "of replacing the original shareholders with converted debt holders, having particular regard of the need to avoid a significant sale of newly-converted equity at a time when it is essential to restore market confidence in the institution").

92. See id. (“[T]he Services of DG Internal Market and Services believe that the resolution trigger is close to the point of failure for an institution, and therefore should be linked to the probability of failure of a bank which is regularly assessed by rating agencies and market participants. However, the Services of DG Internal Market and Services recognise that holders of 'bail-in debt' would want the trigger to be as transparent, objective and predictable as possible, and would welcome views on how this might be designed.”).

93. See David Enrich, Europe Blinks on Bank Test: Regulators Seen Easing 'Stress' Gauge, Undercutting Effort To Restore Confidence, WALL ST. J., Mar. 9, 2011, at A1.

94. Id.; see Gregory J. Lyons et al., Basel Bank Resilience and Liquidity Proposals Confirm the Global Paradigm Shift Toward Increased Financial Regulatory Oversight, 127 BANKING L.J. 226, 239 (2010) (“[T]he FSA proposal would permit capital instruments with 'step ups' and other incentives to redeem to count as Tier 1 capital to a degree.”).

95. For the German definition of Tier 1 capital, see KREDITWESENSGESETZ [KWG] [GERMAN BANKING ACT], Sept. 9, 1998, BGBL. I at 2776, as amended, § 10, ๆ 2(a) (Ger.), which provides definitions of Tier 1 capital for various financial institutions, partnerships, and 
of contingent capital, the FSA does not allow contingent capital, namely, convertible bonds, to be classified as Tier 1 capital, whereas Spain, for instance, allows it. ${ }^{96}$

The EU Commission proposed the harmonization of the Tier 1 definition of capital. ${ }^{97}$ The proposal would allow convertible instrument capital as Tier 1 capital, and contingent capital could be included as an "additional Tier 1 instrument."98 The EU Commission proposal defining Tier 1 could be a first step toward a basic framework for harmonized contingent capital standards. The assurance of Tier 1 status could encourage EU member states to set up rules for contingent capital or leave contingent capital designs up to private ordering. The EU Commission regulation and its harmonization of the Tier 1 capital definition could fill a void left by the Basel Committee. The Basel Committee rejected requests from EU member states to use CCS to satisfy the new capital buffers under Basel III. ${ }^{99}$ Rather, the Committee decided to require SIFIs to use retained earnings and ordinary shares to meet heightened capital requirements. ${ }^{100}$ Although this approach will not fully replace a requirement under Basel III to use CCS to satisfy a new capital buffer, it leaves enough flexibility for counterparties and the legislators in the respective EU member states to implement CCS.

Despite some successful CCS issuances in the past, ${ }^{101}$ the mandatory nature and volume of CCS issuance envisaged by the EU Commission ${ }^{102}$

companies. For public savings and private savings banks, Tier 1 capital consists of the reserves. Id.

96. Enrich, supra note 93.

97. Commission Proposal for a Regulation of the European Parliament and of the Council on Prudential Requirements for Credit Institutions and Investment Firms, at 7478, COM (2011) 452 final (July 20, 2011) [hereinafter EU Commission Proposal].

98. Id.

99. Louis, supra note 83.

100. Id. (noting that this "was a victory for U.S. regulators over their European counterparts," and quoting Karen Shaw Petrou, managing partner of Washington-based Federal Financial Analytics Inc., a bank consulting firm, who stated, "Europeans were pushing for a mix of common equity and contingent capital and they lost at a global level" (internal quotation marks omitted)).

101. A total of five issuances of contingent-like capital securities have occurred: Lloyds issued a contingent capital security in 2009, Unicredit issued a $€ 500$ million Tier 1 security in 2010, Intesa Sanpaolo also issued a Tier 1 security in 2010, Credit Suisse issued Tier 1 contingent capital in 2011, and Rabobank issued contingent notes in 2010 and 2011. GoldMAN SACHS GlOBAL MKTS. InST., supra note 29, at 17.

102. DG WORKING DOCUMENT, supra note 8, at 39, 89 (contemplating what factors to "take into account in determining the correct amount of 'bail-in debt'" and noting that credit institutions will be required to raise their own funds). 
could require the creation of a market in CCS. Market creation will take time. For instance, the European hybrid market, established in 1997, took five years to gain critical mass. ${ }^{103}$ What characteristics potential investors in CCS may desire is unclear, and the risk profile of investors and the resulting volumes may change over time. The required volume of issuance per institution to ensure CCS have the expected impact in a financial weakening of the institution is also unclear. High volumes sold by financial institutions - some estimates suggest between four and nineteen percent of risk-weighted assets of financial institutions ${ }^{104}$ — could lead to increased pricing pressure and increased cost of funding.

Whether single jurisdictions could be deterred from implementing contingent capital requirements without being able to anticipate other jurisdictions' approaches to contingent capital rules is unclear. Legislators in the respective countries may want to pay attention to the competitiveness of their national financial institutions. Without a certain level of convergence in contingent capital rules, ${ }^{105}$ regulatory arbitrage could have an adverse effect on establishing contingent capital as an integral part of financial markets. ${ }^{106}$

Moreover, distorted risk incentives could create drawbacks and undermine the effect of CCS issuances on risk preferences of principalsowners-managers. ${ }^{107}$ More specifically, the incentives originating from corporate governance controls may not work in SIFIs. SIFIs are often considered too big to fail and may be bailed out. ${ }^{108}$ If that is the case, SIFI principals-managers-owners may anticipate a bailout commitment and adjust their risk preferences upwards. ${ }^{109}$ Shareholders who know of an anticipated bailout commitment may demand higher risk-taking. If the SIFI has issued CCS that fulfill the objectives of bail-in, signaling default risk, incentive to increase capital, and less risk-taking, principals, managers, owners, and creditors_-and the market in general—could

103. PAZARBASIOGLU ET AL., supra note 12 , at 12.

104. DG WORKING Document, supra note 8, Annex I, at 89 n.24.

105. See Coffee, supra note 15, at 847 ("International convergence on such a reform is much more possible than on issues such as resolution authority or cross-border bankruptcy, where individual nations have long, complex legal traditions and do not change course easily.”).

106. But see Roberta Romano, Against Financial Regulation Harmonization: A Comment (Nat'l Bureau of Econ. Research, Working Paper No. 414, 2010), available at http://papers.ssrn.com/sol3/papers.cfm?abstract_id=1697348 (noting that one of the dangers of regulatory harmonization is that error on the part of the regulators leads to greater systemic risk).

107. Koziol \& Lawrenz, supra note 30, at 96-98.

108. See Calomiris \& Herring, supra note 46, at 6, 10.

109. FIN. STABILITY BD., supra note 9, at 1 (noting that the risk associated with SIFIs includes moral hazard-their interconnectedness can cause "significant disruption to the wider financial system and economic activity”). 
perceive a too-big-to-fail SIFI as even less likely to fail. This could incentivize the SIFI's principals-managers-owners to shift their risk preferences toward even higher risk profiles. ${ }^{110}$ In the case of a SIFI that issued and converted CCS, the equity holder merely lost the cash flow rights from the coupon but may not lose all control rights. However, the disciplining impact may be mitigated because of the lessening in control rights after conversion. ${ }^{111}$ The lessening in control rights may vary subject to the design features of the respective CCS. ${ }^{112}$ In effect, however, switching to CCS financing could reinforce risk incentives. Additional research may be needed to determine if risk incentives generated by $\mathrm{CCS}^{113}$ may outweigh their potential for risk reduction.

\section{Trends in Europe}

European legislators, regulators, market participants, and lobby groups increasingly demand that management, shareholders, and creditors equally participate in losses resulting from the failure of troubled financial institutions. ${ }^{114}$ In this context, regulators and legislators in Europe appear to be taking the prospect of rules for contingent capital seriously. The EU Commission, the Basel Committee, and Swiss, German, and U.K. legislators have already considered the integration of contingent capital into their regulatory regimes for bank restructuring. ${ }^{115}$

110. See Koziol \& Lawrenz, supra note 30, at 96. But see Flannery, supra note 65, at 15, 18 (suggesting that "reverse convertible debenture" (RCD) — essentially CCS could allow for recapitalization without involving outside parties, such as taxpayers). The trigger would be automatic based on market value and convert at the current share price. Id. at 2. "Issuing RCD as part of a bank's capital structure will then a) protect depositors and taxpayers via a transparent means of automatic re-capitalization, b) cause shareholders to internalize the costs of risk, c) impose no tax penalty on bank shareholders, and d) reduce the incidence of costly failures." Id. at 3 . When RCD is converted, the firm must promptly sell new RCD to replace the lost protection. Id. at 6 . When triggered, only enough RCD would convert as is necessary to recapitalize the firm. Id. at 8, 15 ("Frequent trigger evaluations eliminate moral hazard incentives and expose the RCD to surprisingly low default risk.”).

111. Koziol \& Lawrenz, supra 30, at 98.

112. Our proposal suggests a design with a second trigger that could lower the loss of control after conversion. See infra Part IV.B.

113. See Koziol \& Lawrenz, supra note 30, at 101

114. See The Euro's Real Trouble: The Crisis of the Single Currency Is Political as Much as Financial, ECONOMIsT, July 14, 2011, http://www.economist.com/node/18959279 (noting that Jean-Claude Trichet, president of the European Central Bank, demanded "that future bail-outs must include 'adequate participation of private creditors"”).

115. See DG WORKING DOCUMENT, supra note 8; BUNDESMINISTERIUMS DER JUSTIZ, supra note 34; BANK OF ENG., supra note 34; SwISS REPORT, supra note 34; BASEL 
The EU Commission proposed a comprehensive and targeted approach to restructure and resolve financial institutions. ${ }^{116}$ Under the Commission's comprehensive approach, resolution authorities would have discretion to determine which classes of debt would be converted or written down and at what conversion rate. ${ }^{117}$ The size of the write-down would depend on the financial situation of the institution, its assets and liabilities, and the amount of funds needed "to restore viability and maintain market confidence." approach could help to ensure that debt contracts do not evolve in a way that would reduce overall effectiveness of the Commission's regime. An important motive for the targeted approach was to provide certainty for institutions and creditors about what would happen in a resolution. ${ }^{119}$

The Basel Committee on Banking Supervision, in addressing the systemic risk and interconnectedness of financial institutions, has considered contingent capital and bail-in debt instruments. ${ }^{120}$ Basel II and III already allow the use of "Enhanced Capital Notes""121 and permit the conversion of subordinated debt into equity. ${ }^{122}$ The Basel Committee rejected, however, requests from EU member states to use CCS to satisfy the new capital buffers under Basel III. ${ }^{123}$ Instead, the Basel Committee requires SIFIs to use retained earnings and ordinary shares to meet heightened capital requirements. ${ }^{124}$ An EU Commission proposal would allow contingent capital as an "additional Tier 1 instrument." 125

The Swiss proposal on contingent capital may be the most far-reaching of all European proposals. An important part of the Swiss proposal dealing with systemically important institutions is to allocate nine percent of the total core capital to CCS with predefined triggers. ${ }^{126}$ The proposal

COMM. ON BANKING SUPERVISION, supra note 34. For a summary and critical analysis of European contingent capital proposals, see Henkel \& Kaal, supra note 57.

116. DG WORKING DocumENT, supra note 8, Annex I, at 87-92.

117. Id. at 87.

118. Id. at 88 .

119. Id. at 89.

120. BASEL COMM. ON BANKING SUPERVISION, supra note 34, at 7.

121. See John Glover \& Gavin Finch, Basel Committee Says Bank Bond Investors Should Help Fund Future Bailouts, BLOOMBERG (Aug. 19, 2010), http://www.bloomberg. com/news/2010-08-19/basel-committee-says-bank-bond-investors-should-help-bear-cost-ofbailouts.html.

122. See id.

123. Louis, supra note 83.

124. Id. (noting that this "was a victory for U.S. regulators over their European counterparts," and quoting Karen Shaw Petrou, managing partner of Washington-based Federal Financial Analytics Inc., a bank consulting firm, who stated, "Europeans were pushing for a mix of common equity and contingent capital and they lost at a global level" (internal quotation marks omitted)).

125. See EU Commission Proposal, supra note 97, at 74-78.

126. SWISS REPORT, supra note 34, at 4. 
distinguishes between high and low CCS triggers, ${ }^{127}$ which seems to indicate that a first trigger for conversion from debt into equity could be prioritized to facilitate appropriate calibration. The high and low triggers for contingent capital under the Swiss proposal are conversion triggers. The sequential trigger we propose would add the element of a voting rights increase via the second pre-reorganization trigger. It is important to note, however, that only two Swiss SIFIs, United Bank of Switzerland (UBS) and Credit Suisse, would be subjected to these new rules. ${ }^{128}$ Partially because of the size of these entities in comparison with the Swiss economy, the Swiss have prudently adopted capital requirements that are more stringent than the capital requirements under Basel III. ${ }^{129}$ Both entities have already issued CCS. ${ }^{130}$

The German Financial Institution Reorganization $\mathrm{Act}^{131}$ already provides for a debt-equity swap between a financial institution in reorganization and its creditors. ${ }^{132}$ However, unlike CCS, the debt-equity swap requires creditors' consent under German law. ${ }^{133}$ To remedy the resulting shortcomings, one German proposal included a revision of the German Corporation Act to allow for the implementation of contingent capital. ${ }^{134}$ In short, this German reform proposal focused on providing a statutory basis for the issuance of CCS in Germany. ${ }^{135}$ In the long run, the extent of German reform efforts in this context could follow proposed changes by the Basel Committee and its use of contingent capital in Basel III. ${ }^{136}$ Reforms in German law pertaining to contingent capital would likely

127. Id. at 25 .

128. Id. at 74 .

129. Coffee, supra note 15 , at 803 n.23.

130. See SwISs RePort, supra note 34, at 9; see also Goldman SACHS Global MKTS. INST., supra note 29, at 19 (discussing capital requirements at UBS and Credit Suisse).

131. KREDitinstitute-REORGANIZATIONSGESETZ [KREDREORG] [FINANCIAL InStITUTION REORGANIZATION ACT], Dec. 9, 2010, BGBL. I at 1900 (Ger.).

132. Id. § 9, $₫ 1$.

133. Id.

134. BUNDESMINISTERIUMS DER JUSTIZ, supra note 34

135. The reform of the German Stock Corporation Act is centered around sections 192, 194, and 221 of AktG. Under prior German law, the instrument of "mandatory convertible bonds"- "Pflichtwandelschuldverschreibungen”- had already been recognized. For more on section 221 of the AktG, see AKTG: GROßKOMMENTAR (Heribert Hirte \& Kai Hasselbach eds., 2005).

136. StefFen Schneider \& MARKus SÖHNCHEN, RetTung vON Kreditinstituten IN DER KRISE DURCH CONTINGENT CONVERTIBle BondS-PFliChTWANDELSCHUldVER SCHREIBUNGEN FÜR BANKEN (“COCO-BONDS”), available at http://www.forum-institut.de/ fileadmin/data/Bereich_3/Rettung_von_Finanzinstituten_in_der_Krise.pdf. See supra Part II.C for discussion on the Basel Committee's decision not to integrate contingent capital. 
require substantial changes in other areas of German law. ${ }^{137}$ Unless required by an EU directive or regulation, an overhaul of several areas of German law may not be easily implemented.

The Bank of England suggests that contingent capital will result in higher loss absorbency and proposes precautionary and non-viability contingent capital. $^{138}$ In the United Kingdom, Lloyds Bank ${ }^{139}$ and, in the Netherlands, Rabobank ${ }^{140}$ issued CCS in 2010. ${ }^{141}$ Barclays is currently working on the issuance of similar securities. ${ }^{142}$ Britain's Insolvency Act allows for "company voluntary arrangements," a concept similar to traditional debtequity swaps. ${ }^{143}$ Although these developments are encouraging signs, possibly suggesting an impending development of a market in CCS, the U.K. Independent Commission on Banking opined in an interim report that important questions remain to be answered in the context of the use of CCS instruments to build up capital. ${ }^{144}$

\section{EUROPEAN COMMISSION PROPOSAL}

The European Commission, through the Internal Market and Services Directorate General (DG Market), ${ }^{145}$ issued a working document for discussion and consultation purposes that discusses the potential use of contingent capital. ${ }^{146}$ The draft proposes a targeted and comprehensive

137. SCHNEIDER \& SÖHNCHEN, supra note 136 (opining that the new Act would require a change of the Banking Act (KWG), the Limited Act, the Stock Corporation Act, the Bankruptcy Act, and the Schuldverschreibungsgesetzes).

138. BANK OF ENG., supra note 34, at 56.

139. Glover \& Finch, supra note 121.

140. A Boost for Contingent-Capital Deals?, N.Y. Times DeAlBook (Mar. 9, 2010), http://dealbook.nytimes.com/2010/03/09/a-boost-for-contingent-capital-deals.

141. George M. von Furstenberg, Contingent Capital To Strengthen the Private Safety Net for Financial Institutions: CoCos to the Rescue? 10 (Deutsche Bundesbank Eurosystem, Discussion Paper, Series 2, Banking \& Fin. Studies, No. 01, 2011).

142. Patrick Jenkins, Barclays Set To Follow Swiss Lead, Fin. Times (Eng.) (Feb. 14, 2011), http://www.ft.com/cms/s/0/7f3c49ea-386e-11e0-959c-00144feabdc0.html\#axz z1SZdsn94g.

143. See, e.g., Insolvency Act, (1986) § 1, 4(2) HaLs. STAT. (4th ed.) 85-100 (Eng.).

144. INDEP. COMM'N ON BANKING, INTERIM REPORT: CONSULTATION ON REFORM OPTIONS 180-82 (2011) (U.K.), http://s3-eu-west-1.amazonaws.com/htcdn/Interim-Report110411.pdf (questioning, in the context of contingent capital, who would buy contingent capital and what would be the "possible dynamic effects at or near to the trigger point").

145. The DG Internal Market is one of the Directorates General, which make up the European Commission. A main role of the DG Internal Market is to coordinate the Commission's policy on the European Single Market. Its primary function is to seek the removal of unjustified obstacles to trade. DG Internal Market and Services, EuROPEAN CoMm’n, http://ec.europa.eu/dgs/internal_market/index_en.htm (last visited Feb. 18, 2012).

146. See DG Working DocumenT, supra note 8, Annex I, at 86-87; see also EU Commission Proposal, supra note 97, at 74-78 (setting out the more recent EU Commission proposal suggesting harmonization of the definition of Tier 1 capital including convertible instruments). 
approach to restructure and resolve financial institutions ${ }^{147}$ and recommends the mandatory issuance of CCS for systemically important banks. ${ }^{148}$ The proposal suggests financial institutions could be required to issue CCS in volumes between four and nineteen percent of risk-weighted assets. ${ }^{149}$ Other estimates for mandatory issuance of CCS range from four to eight percent of risk-weighted assets. ${ }^{150}$ Despite the many open design and market development issues, ${ }^{151}$ there seems to be consensus that there is potential for a market in CCS. ${ }^{152}$ The design features suggested by the EU Commission, in their final form, have the potential to impact the volume of CCS issuance. They could affect the depth and potential volatility of the CCS market worldwide.

\section{A. The Comprehensive Approach}

As part of the new framework, the EU Commission proposed a “comprehensive approach.,"153 Upon an institution's triggering resolution, resolution authorities would be given the statutory power to write down or convert to an equity claim all senior debt necessary to ensure the credit institution is returned to solvency. ${ }^{154}$ This power would not be applied retroactively - not to existing debt but only to new debt issued after the power was lawfully enacted. ${ }^{155}$

Under this proposal, resolution authorities would have discretion to determine which classes of debt would be converted or written down and at what conversion rate. ${ }^{156}$ The Commission proposal provides that the size of the write-down would depend on the financial situation of the institution, its assets and liabilities, and the amount of funds needed "to restore viability and maintain market confidence." ${ }^{157}$

147. DG WORKING Document, supra note 8, Annex I, at 87-90.

148. See id. at 32, 86 (recognizing that contingent capital will likely be most useful with systemically important banks, but considering applying the resolution to all credit institutions).

149. Id. at 89 n.24.

150. See, e.g., Goldman SACHS Global MKTs. Inst., supra note 29, at 13.

151. See supra Part II.B.

152. See Goldman SACHS GlOBAL MKTS. Inst., supra note 29, at 3.

153. DG WORKING Document, supra note 8, Annex I, at 87-89.

154. See id. at 87.

155. Id.

156. Id.

157. Id. at 88 . 
The proposal envisages excluding the following instruments: shortterm debt as defined by a specified maximum maturity, ${ }^{158}$ swap repo and derivative counterparties, and other trade creditors, as well as retail and wholesale deposits and secured debt. ${ }^{159}$ The exclusions are deemed necessary for the proper functioning of credit markets. ${ }^{160}$ In summary, the Commission considers this proposed regime adequate to "create maximum flexibility for the resolution authorities to return an institution to viability, install new management, and implement a recovery or restructuring plan to retain market confidence and access to funding." 161

\section{B. The Targeted Approach}

Under the "targeted approach," and in stark contrast to the comprehensive approach, resolution authorities would require credit institutions to issue a fixed amount of debt that would prequalify for write-down or convert into equity on a statutory trigger. ${ }^{162}$ The Commission suggests that the prequalified amount of debt could include a fixed minimum for all institutions, which could be between four and nineteen percent of riskweighted assets because that was the range of "public interventions during the crisis." "163 The underlying rationale for this proposal is "to ensure that debt contracts are not able [to] evolve in a way that would reduce the effectiveness of the regime and would provide certainty for both the institution and creditors about what would happen in a resolution."164 The EBA is tasked with ensuring the consistent treatment of prequalified debt that can be written down or converted into equity across jurisdictions.

The market reaction to the news of the EU Commission proposal (DG Market) could suggest that the pricing of financial debt instruments may be affected. ${ }^{165}$ The EU Commission proposal is likely to require substantial

158. But see Coffee, supra note 15, at 833 (arguing that the amount of contingent capital that should be triggered ought to be defined by short-term debt).

159. DG WORKING DOCUMENT, supra note 8, Annex I, at 88.

160. See id.

161. Id.

162. See id. at 89 ("Such debt would need to include a contractual term which would specify that the relevant resolution authority could use a statutory power to write down the debt when the institution meets the trigger conditions for entry into resolution.”).

163. Id. at $89 \&$ n. 24 .

164. Id. at 89 .

165. See EuROPEAn BANKING FeD., supra note 86, at 5, 53-55 (positing that global harmonization is critical "to ensure a level playing field," but before any bail-in measures are implemented, greater clarification and an impact analysis are essential-with regard to the comprehensive approach, pointing out that it will create a level playing field in Europe but would be globally unbalanced resulting in investors' looking outside the European Union to invest in debts). 
international coordination and presents numerous complex issues, among them the uncertainty of its knock-on effect and interaction with other proposals-including Basel III. ${ }^{166}$ Given the complexity of the regulatory and tax issues and the need for international coordination, the legislative timetable may also require adjustments. ${ }^{167}$ There is also a perceived risk that the implementation of the debt write-down in the EU Commission proposal will increase banks' funding costs. ${ }^{168}$ Although the concept may provide greater certainty and discretion to regulators, it could result in greater market uncertainty, which is likely to increase costs, and could have the unintended effect of actually increasing the size of financial institutions. ${ }^{169}$

A core benefit of the targeted approach is its ability to contractually set terms of conversion and its timing, which could result in greater clarity and pricing, thus more accurately reflecting risk. ${ }^{170}$ However, in

166. See Henkel \& Kaal, supra note 57; PETER M. Werner \& EdWARD Murray, INT'L SWAPS \& DERIVATIVES Ass'N, POSSIBLE EU FRAMEWORK FOR BANK RECOVERY \& RESOLUTION 3-4, 18-21 (2011), available at http://www.isdadocs.org/speeches/pdf/EU_ CrossBorderCrisisMgmt_ISDAResponse_Mar11.pdf (responding to the "comprehensive EU framework for troubled and failing banks” and averring the following with regard to the debt write-down ("bail-in") proposal: (1) international coordination for debt writedown is essential; (2) the proposal presents numerous complex issues such as interaction with other proposals - including Basel III, regulatory issues, and tax issues; (3) because of the need for international coordination and the complex issues presented, the legislative timetable is "unrealistic" and debt write-down should be tabled until some of these issues have been resolved). The International Swaps and Derivatives Association (ISDA) also contends that the debt write-down proposal would impact derivative transactions and argues that derivatives exposures "are not an appropriate form of debt to make subject to the write-down power." Id. at 20. And lastly, ISDA emphasizes the importance of clarification and certainty with regard to the scope of the debt write-down regime. Id.

167. See Werner \& MURRAY, supra note 166, at 19.

168. See Ass'N OF British InSURERS, THE ABI's Response tO DG INTERNAL Market Services: Technical Details of a Possible EU Framework for Bank RECOVERY AND RESOLUTION 5-6 (2011), available at http://www.abi.org.uk/Media/ Consultation_Papers/Consultation_Responses.aspx (noting that regardless of its members' positive or negative views, the implementation of the debt write-down will increase banks' funding costs). Because this creates greater risk, it will increase costs, and this will "have the unintended effect of promoting greater concentration into larger banks." Id. at 6. Ultimately, there is concern that the increased complexity will affect implementation and will not benefit an efficient funding sector. Id. at 6-7.

169. Id. at 6.

170. See Ass'n for Fin. MKTs. in Eur., Response to the EUROPEAN COMMISSION Consultation on Technical Details of a Possible EU Framework fOR Bank RECOVERY \& RESOLUTION 1, 54-56 (2011), available at http://www.afme.eu/ Documents/ Consultation-Responses.aspx (pointing out the two approaches to debt write-down proposed by the European Commission: (1) the "targeted" approach, which "would require banks 
the coming years, banks could be confronted with increased competition for retail deposits. This could increase the use of other forms of secured funding. As a result of increased rates and competition, funding could become less stable. ${ }^{171}$ There could also be a risk that contractual arrangements for CCS could be triggered before a statutory bail-in is applied. $^{172}$ And the new approach suggested by the Commission could impact investor confidence in the covered bond markets and perhaps affect their efficiency. ${ }^{173}$

Although the debt write-down could serve as a powerful resolution tool, such a regime would probably benefit from international coordinationperhaps with the Basel Committee and Financial Stability Board. ${ }^{174}$ The market impact of the proposal may require careful planning to create a

to hold a fixed amount of 'bail-in-able' debt but that would exclude senior debt from the scope of any write-down"; and (2) the "comprehensive" approach, which would allow RAs to write down senior debt). The Association for Financial Markets in Europe (AFME) states its members primarily support the "ease and clarity" of the targeted approach over the comprehensive approach. Id. at 54. The targeted approach could contractually set terms of conversion and timing resulting in greater clarity and prices that more accurately reflect risk. Id. AFME also recommends that the targeted approach be coordinated with Basel III and, ultimately, that the protection provided be studied. Id. at 55. AFME suggests that the comprehensive approach could be available to regulators as a "last resort" when the targeted approach proves inadequate. Id. at 56.

171. DAVID HisCoCK, INT’L CAPITAL MKT. Ass'N, ReSPONSE SubMisSiON Re: EuROPEAN COMMISSION CONSUlTATION PAPER-TECHNICAL DETAILS OF A POSSIBLE EUROPEAN CRISIS MANAGEMENT FRAMEWORK 1-2 (2011), availabe at http://www.icmagroup.org/ICMAGroup/ files/c7/c7a2c1bd-f34c-4aaa-b75b-5ab648c16345.pdf (expressing concern that the bail-in regime will effectively increase rates for depositors by encumbering higher quality assets). The International Capital Market Association (ICMA) notes that one positive aspect of the targeted approach is that investors may precisely express investment preferences. This creates a "fairer transition to a new regime than simply imposing bail-in on existing investors.” Id. at 4.

172. See Ministry of Fin. ET AL., Swedish ANSWERS TO the DG INTERnAl Market and Services Working Document “Technical Details of a Possible EU FRAMEWORK FOR BANK RECOVERY AND RESOLUTION” 1, 43-44 (2011) (Swed.), available at http://www.riksbank.se/upload/Dokument_riksbank/Kat_publicerat/Remisser/2011/ Consultation_030311.pdf (asserting generally that the untested bail-in regime should not be relied upon-if the bail-in tool can be shown to be effective, it may be useful as a wind-down tool - and arguing specifically that the wind-down tools should include a statutory bail-in tool, which would serve to "impose market discipline on unsecured debt holders as they can impose losses on those creditors"). The Riksbank further suggests that "[c]ontractual bail in instruments must trigger before a statutory bail in is applied. Regulatory capital instruments must bear losses before any higher ranking debt" because such a scheme should still leave "the troubled bank[s] well capitalized." Id. at 44 .

173. See ReAlKREDitrÅdet (Ass’n OF DANish MORTG. BANKS), CONSUltation REsPonse Concerning TeCHNiCAl Details of A Possible EU FrameWORK FOR BANK RECOVERY AND RESOLUTION 1-2, 9 (2011), available at http://www.realkreditraadet. dk/Files/Filer/6\%20Aktuelt/Hringssvar/2011/Response\%20concerning\%20Technical\%2 0details\%20of\%20a\%20possible\%20EU\%20Framework\%20for\%20Bank\%20Recovery \%20and\%20Resolution.pdf.

174. See Henkel \& Kaal, supra note 57. 
high level of certainty for market participants. ${ }^{175}$ The International Monetary Fund suggests that the following areas should be explored in detail before using debt write-down instruments: the order of priority in an insolvency proceeding, and coordination across jurisdictions; the interaction of debt write-down with other resolution tools; the option to give some creditors "super-senior status" and claw back provisions. ${ }^{176}$ Some question how the appropriate issuance level and cost will be determined and note that only a very limited group of investors may be interested in these instruments. ${ }^{177}$ It is also not clear what classes of debt should be excluded from a statutory power to write-down debt. ${ }^{178}$ More specifically, secured debt as well as derivatives used to hedge risks between loans and covered bonds could require exclusion. ${ }^{179}$

\section{SEQUENTIAL TRIGGERS AS PART OF THE EUROPEAN COMMISSION'S TARGETED APPROACH}

The basis for the sequential trigger design proposed in this Article is the EU Commission's targeted approach. As an addition to the targeted approach, we suggest a second trigger of contingent capital before the resolution of a financial institution but after conversion into equity. Other scholars have discussed the use of second triggers for contingent capital. ${ }^{180}$ The existing proposals for a second trigger design, however, make no reference to the restructuring of financial institutions or the proposal by the EU Commission in that context. Most of the existing proposals suggesting second triggers in contingent capital try to optimize the first trigger by adding certain additional characteristics or trigger mechanisms, ${ }^{181}$ mostly to avoid manipulation.

175. InT'L Monetary Fund, European Commission Consultation: TeCHNiCAL DETAILS OF A POSSIBLE EU FRAMEWORK FOR BANK RECOVERY AND RESOLUTION 8 (2011), available at http://www.imf.org/external/np/eur/2011/pdf/030311.pdf.

176. Id.

177. Id.

178. ReAlKReditrÅdet (Ass'N OF DANish Mortg. BANKs), supra note 173, at 8 app.B.

179. See id.

180. See, e.g., McDonald, supra note 39, at 2; Pennacchi, supra note 45, at 12, 24 (considering the effects of the dual-price conversion trigger proposed by McDonald and noting that although the dual-price trigger acts like a single-price trigger in times of stress, in a noncrisis the dual-price trigger contingent capital acts like standard subordinated debt).

181. See discussion infra Part IV.B. 
One model suggests converting debt into equity if both (1) "the firm's stock price is at or below a trigger value," and (2) "the value of a financial institution's index is also at or below a trigger value.”182 The strength of this proposal is that "capital converts automatically based on market prices, without reference to accounting-based measures of capital.”183 The model thus avoids the lack of reliability and precision that is often attributed to accounting-based measures of capital. Although the strength of this proposal is its reliance on market prices, a disadvantage could be the index trigger, which could result in index manipulation or an attempt to force the entity into bankruptcy. ${ }^{184}$ Another model considers the effect of a dual-price conversion trigger and observes that a dual-price trigger acts like a single-price trigger in times of stress, but outside of crises, contingent capital with a dual-price trigger acts like standard subordinated debt, and "yields on dual-price trigger contingent capital fall between those of comparable single price trigger contingent capital and subordinated debt.",185 Others observe in this context that "[s]ince two prices are possible whenever the firm's value drops to a certain level, by combining these dual equilibria around trigger at different times in the future, numerous expected equity values are possible even well before conversion.,"186

\section{A. First Trigger: Debt-Equity Conversion}

The design features of the debt-equity conversion trigger are an integral part of the design features of the second reorganizational trigger proposed in this Article. Assuming a predefined mandatory issuance of CCS under EU law, ${ }^{187}$ CCS could convert into equity based on various models. ${ }^{188}$

182. McDonald, supra note 39, at 4-9 (providing an example of contingent capital with dual triggers and comparing such a model with other structures). Further, McDonald discusses various issues related to evaluating contingent capital proposals, including the effect of market manipulation, capital errors - such as contingent capital converting into equity when not required and contingent capital failing to convert into equity when it is required-and problems with reliance on accounting measures. Id. at 9-10, 18-24.

183. Id. at 2

184. Id. at 13 .

185. Pennacchi, supra note 45, at 27-28 (noting further that "[t]he effect of a dual price trigger for conversion is to make contingent capital a blend of non-convertible subordinated debt and standard single price trigger contingent capital”).

186. See Sundaresan \& Wang, supra note 39, at 6 (recognizing that a value transfer between equity and contingent capital "disturbs equilibrium by moving the stock price up or down depending on the conversion ratio" and that the proposals typically ensure there is no value transfer at maturity, but do not ensure there is no transfer before maturity). Because the value transfer will not always push the stock price across the trigger, there are two possible scenarios, that is, equilibria: (1) "all investors believe conversion will not happen, leading the equity value to stay above the trigger," and (2) "all investors believe conversion will happen, leading the equity value to hit the trigger." Id. at 6-7.

187. See DG MARKET Document, supra note 8, Annex I, at 89 (explaining that the targeted approach would "require credit institutions to issue a fixed volume of 'bail-in 
Jack Coffee's proposal to convert CCS "into a fixed return preferred stock with cumulative arrearages and significant voting rights"189 has many redeeming qualities. Via the first trigger with "significant voting rights," Coffee's proposal would create a "countervailing voting constituency to offset the voting power of risk-tolerant common shareholders."190 This could create a class of stockholders that is resistant to increased leverage and higher risk. Coffee also discusses the use of "super-voting."191 Although we agree with the need for increased voting rights, the proposal in this Article would allocate super-voting rights to CCS holders only if the first trigger did not result in an improvement of the financial institution's financial health. The first trigger in this Article's proposal would give the new CCS shareholder one vote per stock. Only upon the realization of a continuing downward trend, perhaps caused by a negative market reaction after the first (incremental) conversion of CCS, should the voting rights be increased. At that point, the voting rights increase should be

able’ debt”); Goldman SACHS GlOBAL MKTs. Inst., supra note 29, at 19 (noting that the Swiss have already required contingent capital and that the proposed securities require two tranches of contingent capital).

188. See Coffee, supra note 15, at 828; Flannery, supra note 65, at 6; McDonald, supra note 39, at 1 . But see Dudley, supra note 62, at 4 (proposing that CCS would trigger "if a bank's share price were to fall precipitously"); Duffie, supra note 53, at 4-6; Hart \& Zingales, supra note 60, at 5-7 (pointing out three potential shortcomings in Flannery's proposal: (1) "it is too lenient toward management, eliminating one of the disciplinary effects of debt"; (2) "it can have perverse effects: the manager talking down the stock so as to obtain more slack"; (3) "it generates multiple equilibria, some of which are inefficient"). The triggers "could be tied to deterioration in the condition of the specific banking institution and/or to the banking system as a whole." Dudley, supra note 62 , at 6 . Converting debt into common shares might work better when tied to market-based measures because market-based measures tend to lead regulatorybased measures. Id. The cost of CCS would be reduced if the debt holder can "expect to get out at or close to whole.” Id. at 7. Also, there would be a greater scope of adjustment in a market-based measure, lowering the cost. Id. Furthermore, CCS could be a more "straightforward and efficient way to achieve a countercyclical regulatory capital regime." Id. at 6; see also STRONGIN ET AL., supra note 10, at 4 (explaining that CCS may be "ineffective or even dangerous" if the trigger mechanisms are based on market prices for this may worsen bank runs, rather than prevent them). The trigger must occur before insolvency and be quick and transparent, and the amount of contingent capital must be sufficient to deal with the crisis. Id. When the trigger is reached, firms could have thirty days to recapitalize or contingent capital would convert. Id. We suggest that contingent capital holdings equivalent to six percent of risk-weighted assets would be sufficient to have the firms recapitalize voluntarily instead of converting the contingent capital.

189. Coffee, supra note 15, at 806.

190. Id.

191. Id. at 832. 
significant enough to result in a change of control over the company. Coffee considers a change of control only for arrearages, ${ }^{192}$ taking effect after two or three years. ${ }^{193}$

The proposal in this Article would allow the change of control much sooner depending on the improvement in financial health after the first trigger. To balance the constituents' incentives and avoid abuse, ${ }^{194}$ the voting rights increase could be calibrated to give CCS holders a majority stake in the company only with, for instance, the largest institutional shareholder. The CCS contract or the corporation's charter could specifically provide for change of control in the very limited case of a lack of success of the first trigger and only in combination with the largest institutional shareholder. An advantage of this approach could be the enhanced role of institutional shareholders and the potential threat to incumbent diversified shareholders. In addition to the creation of "a countervailing voting constituency to offset the voting power of risk-tolerant shareholders, thereby reducing the pressure on corporate managers to accept greater risk and leverage," 195 the proposal in this Article would further incentivize institutional shareholders to monitor management and assess the level of risk-taking in the respective market environment. It could be another level of check and balances, truly independent of the company's internal governance.

Some may argue that this proposal, if implemented, could lead to manipulation of the sequential triggering events and abusive practices, such as asset stripping in the vicinity of bankruptcy. To avoid such practices, the CCS contract or the charter of the corporation could require a mandatory holding period for CCS. The mandatory holding period could be extended until after bankruptcy. But even without such a holding

192. Id. This condition may not exist in every jurisdiction in Europe; for example, in Germany the Financial Supervisory Authority has the power to prohibit or limit any withdrawal or distribution of profits, thus making a vote increase under Professor Coffee's proposal unnecessary. See KREDITWESENSGESETZ [KWG] [GERMAN BANKING Act], Sept. 9, 1998, BGBL. I at 2776, as amended, § 45, ๆ 2, no. 1 (Ger.).

193. Coffee, supra note 15, at 832-33. Although he suggests "significant voting rights," id. at 806, Coffee limits the application of a change in control, stating:

[T] protect this right to cumulative dividends, it would be appropriate to give the preferred an additional voting right: the right to elect as a class some additional percentage of the directors each year that their dividend is omitted. The right to such class voting would end once the arrearages were fully paid. On this basis, control of the corporation might pass to the preferred shareholders within two or three years if the arrearages were not eliminated.

Id. at 832-33.

194. Hedge funds could be interested in acquiring CCS with sequential triggers that give them super-voting rights to control the company before bankruptcy for their financial benefit. They could, for instance, sell the company's most valuable assets at a profit and then push the remainder into bankruptcy.

195. Coffee, supra note 15, at 806 . 
period, the main purpose of the proposal in this Article and the reasoning behind the second trigger is to avoid reaching the vicinity of bankruptcy at the early stage of conversion. The advantage of our proposal is twofold: we hope to (1) incentivize shareholders to participate in the reorganization of the bank by not immediately threatening shareholders with a takeover by creditors, and (2) allow for a "soft landing" similar to a Chapter 11 procedure by providing additional time and avoiding a fire sale of assets. The European Commission has recognized that a breach of capital requirements by a bank may not necessarily mean that the institution is encountering serious problems, which inevitably would lead to failure. ${ }^{196}$ The conversion following the first trigger does not have the same finality as that in Coffee's proposal; it does not necessarily mean that creditors will take over the institution, unless it further deteriorates. The proposal advanced here may be more predictable with the advantage of higher marketability because of the potentially increased willingness of rating agencies to rate CCS with sequential triggers. ${ }^{197}$

\section{B. Second Trigger}

At the core of this Article are suggestions for a potential design of sequential triggers with the second trigger before reorganization of the SIFI. The second reorganization trigger would increase voting rights for holders of contingent capital after conversion to equity at the prevention stage and could be comparable to a super-voting stock under Delaware law. Using a predefined threshold for the improvement of the financial health of a company after the first trigger, we propose that if the financial health of the institution should not return after the first preventive trigger, the voting rights of contingent capital holders could be increased by a predefined level to give the holders of CCS more influence in the resolution phase of the SIFIs.

Quantifying the improvement of the company after the first trigger could depend on many factors. The continuing evaluation of the specific market-based factors used in the design of the first trigger could be a starting point for assessing the financial improvement of the company.

196. Communication from the Commission to the European Parliament, the Council, the European Economic and Social Committee, the Committee of the Regions and the European Central Bank: An EU Framework for Crisis Management in the Financial Sector, at 7, COM (2010) 579 final (Oct. 20, 2010).

197. See supra Part I. 
For instance, if the first trigger were based on a combination of credit default swap (CDS) spreads and debt-equity ratios, both measures could be used to assess the financial health of the company after the conversion. If both measures showed a predefined threshold of improvement in a time period between three and six months after the first (incremental) trigger, the second voting rights trigger could be avoided. The incentives for management and shareholders to show sufficient improvement after the first trigger could give the second voting rights trigger an important role in securing the success of the first trigger.

In addition to providing super-voting rights and increasing dilution, the second trigger can act as a reorganization tool independent of management decisions or corrective action by regulators. The second trigger could also increase the marketability of CCS and could allow rating agencies to adequately assess this form of convertible securities. By focusing on the multiple uses of contingent capital in different phases, the proposal could create more flexibility and generate many indirect effects and knock-on effects that could perhaps help improve shortcomings of CCS designs with only one trigger. ${ }^{198}$ The information asymmetries between market participants and a SIFI's management before a SIFI defaults ${ }^{199}$ could be minimized if a financial weakening of the SIFI after conversion of CCS triggers a voting rights increase. The voting rights increase, in effect, would signal continuing default risk to investors. Signaling default risk after the first rather than the second trigger could result in adverse market consequences. The second trigger would have the capacity to adjust and remedy these adverse consequences.

\section{Objective Automatic Institution-Specific Trigger}

Important to the effectuation of an efficient voting rights increase is the nature of the second trigger. Several approaches with corresponding legal and economic effects are possible. ${ }^{200}$ The second trigger could be an institution-specific trigger or a systemic trigger. Systemic triggers could be either regulatory or statutory. A regulatory systemic trigger could be, for instance, a bank stress test ${ }^{201}$ or a determination by a regulator that the

198. See supra Part II.B (discussing the shortcomings in single trigger designs).

199. In the case of Lehman Brothers, the company was still trying to negotiate a merger when it probably should have been clear that the company would not be able to survive without a federal bailout. See Ayotte \& Skeel, supra note 1, at 470 . Under the proposal in this Article, the first and second CCS triggers would probably have signaled default risk to market participants.

200. For possible economic effects of different trigger designs, see Henkel \& Kaal, supra note 57.

201. Patrick Jenkins, Banks Stress Test Pass Rate Under Fire, Fin. TimEs (Eng.) (July 16, 2011), http://www.ft.com/intl/cms/s/0/dc111364-aefa-11e0-bb89-00144feabdc0.html 
bank is not financially viable without a public sector injection or write off. $^{202}$ An institution-specific trigger could be transactional or automatic. A transactional institution-specific trigger could define in contractual terms if, how, and when the increase in voting rights may be triggered. An automatic institution-specific trigger could cause the voting rights increase if, for instance, the debt-equity ratio, the share price or a share price-based ratio, or a CDS spread of a financial institution passes a certain threshold.

The holders of contingent capital, whose debt securities would have converted into equity securities at that point, would receive increased voting rights if the financial situation of the institution did not improve after CCS conversion into equity. The adequate increase in voting rights pre-resolution would need to be triggered by evidence that the conversion into equity was not successful, that conversion was triggered too early or too late, or that there was an overall continuing downward trend in the financial performance of the company. To achieve this objective, the approach of this Article favors an objective automatic institution-specific second trigger for the voting rights increase. The improvement of the financial institution could be measured objectively through a combination of debt-equity ratio improvement and CDS spread narrowing after conversion. The exact arithmetic would have to be institution specific and is not the subject of this Article. Similarly, the calibration of sequential triggers may also have to be institution specific.

\section{Voting Rights Increase for CCS Holders}

The holders of contingent capital, whose debt securities would have converted into equity securities at that point, would receive increased voting rights if the financial situation of the institution did not improve after conversion into equity. The increased voting rights will be handled differently by different jurisdictions.

\#axzz1TdjsXOko (pointing out that in Europe, “[o]nly nine banks failed the long-running stress test carried out on 91 European banks, in a result that potentially undermines claims the exercise was tough enough to restore investors' faith in the eurozone financial system").

202. See BAsel Comm. ON BAnKing Supervision, supra note 34 , at 1,7 (announcing that the Basel Committee is "developing a proposal on a methodology comprising both quantitative and qualitative indicators to assess the systemic importance of financial institutions at a global level”). 


\section{a. Law of EU Member States}

Similar to U.S. law, German corporate law generally requires that a shareholder's vote matches the respective capital contribution, that is, one share/one vote. ${ }^{203}$ However, until 1998, German corporate law allowed the limitation of voting rights up to a certain limit. ${ }^{204}$ Once such a limitation-Höchststimmrechte-was in place, additional capital contributions did not increase the voting power. Höchststimmrechte were used to defend against hostile takeovers ${ }^{205}$ and have been cited as a cause for losses in stock prices. ${ }^{206}$ In part because of increasing criticism, on April 27, 1998, Höchststimmrechte were banned for listed German corporations. $^{207}$ Conversely, German corporate law allows an increase in voting rights only in very limited circumstances, such as grandfathering provisions for shares with multiple voting rights that were created before the enactment of the Corporations $\mathrm{Act}^{208}$ or were deemed admissible by the highest authorities under exceptional circumstances. ${ }^{209}$

Other European countries, such as France and the United Kingdom, allow increases in voting rights. France allows charters that provide for multiple votes per share or a limitation of voting rights. ${ }^{210}$ In the United

203. AKTiENGESETZ [AKtG] [STOCK CoRporation Act], Sept. 6, 1965, BGBL. I, §§ 12, 134, last amended by GESETZ [G], Dec. 9, 2010, BGBL. I at 1900, art. 6 (Ger.).

204. UWE HÜFFER, AKTIENGESETZ § 234, at 1160-61 (2008).

205. Antje Endell, Volkswagen im Angebot VW-Gesetz bietet keinen dauerhaften Schutz vor feindlicher Übernahme, 3 NEUE ZEITSCHRIFT FÜR GESELLSCHAFTSRECHT 1160, 1160-61 (2000) (arguing Deutsche Bank and Mannesman implemented Höchststimmrechte in their charters allowing them to discount votes of shareholders in a hostile takeover).

206. Id.; see Ekkehard Wenger, Universalbankensystem und Depotstimmrecht, in DER MARKT FÜr UnTERNEHMENSKONTROLLEN 73, 98 n.84 (Helmut Gröner ed., 1992) (arguing that on average Höchststimmrechte have caused about four percent in stock price losses). Contra Endell, supra note 205, at 1160-61 (arguing that stock price losses cannot be attributed to Höchststimmrechte). See also Michael Adams, Höchststimmrechte, Mehrfachstimmrechte und sonstige wundersame Hindernisse auf dem Markt für Unternehmenskontrolle, 35 DiE AKTIENGESELlschafT 63, 71 (1990); Theodor Baums, Höchststimmrechte, 35 DiE AKTIENGESELLSCHAFT 221, 226 (1990).

207. GESETZ ZUR KONTROLLE UND TRANSPARENZ IM UNTERNEHMENSBEREICH [KonTraG] [Control and Transparency in Business Act], Apr. 27, 1998, BGBl. I at 786, arts. 1-2 (Ger.), available at http://www.ias-rechnungslegung.com/inhalt/gesetzl _grundl/kontrag/kontrag_bundesgestzesblatt.pdf (leading to a change of section 134 of the AktG); see also HÜFFER, supra note 204, § 234, at 1159-61.

208. See EINFÜHRUNGSGESETZ ZUM AKTIENGESETZ [EGAKTG] [INTRODUCTORY ACT TO THE STOCK CORPORATION ACT], Sept. 6, 1965, BGBL. I at 1185, $\S 5$, last amended by GESETZ [G], Sept. 12, 2010, BGBL. I at 1900, art. 7 (Ger.); AKTG § 12 (Ger.); AdoLF BAUMBACH \& ALFRED HUECK, GMBHG § 12, at 3-4, 6 (2010)

209. BAUMBACH \& HUECK, supra note 208, § 12, at 5 .

210. Code De CoMmerce [C. COM.] art. 225-122 (Fr.). 
Kingdom, multiple votes per share are also permissible because the right of shareholder votes is governed by principles of freedom of contract. ${ }^{211}$

Although not formally recognized under German Corporate Law, contingent capital is already recognized in Germany based on case law. ${ }^{212}$ Voting right increases could perhaps be introduced at a later point when the legislature formalizes its reform efforts. A prerequisite for the voting rights increase could be the conversion of contingent capital into equity capital. Another prerequisite for the increase could be a further worsening of the SIFI's financial condition after conversion. The implementation of these proposals could keep Germany competitive with other European countries that allow an increase in voting rights, such as the United Kingdom and France. ${ }^{213}$

\section{b. U.S. Law}

United States state law does not uniformly address shareholder dilution involving the issuance or conversion of convertible securities. In some states, preemptive rights are triggered when convertible securities are issued. ${ }^{214}$ In others, preemptive rights are not automatically provided when convertible securities are issued or converted, unless provided for in the articles of incorporation. ${ }^{215}$ Although some state statutes provide an enumeration of exceptions to preemptive rights, the issuance of convertible securities is generally not included. ${ }^{216}$

211. See Paul L. Davies, Gower and Davies’ Principles of Modern Company LaW 416, 420 (8th ed. 2008).

212. See supra note 134

213. See supra Part I.

214. See, e.g., MinN. STAT. ANN. § 302A.413 (West 2004) (providing generally for an opt-out provision for preemptive rights- "Unless denied or limited in the articles or by the board ... . a shareholder of a corporation has the preemptive rights provided in this section"-and specifically providing that the preemptive right accrues when the corporation proposes to issue new or additional securities other than shares that are convertible into "the same class as the shares held by the shareholder").

215. See, e.g., CAL. CORP. CODE § 406 (West 2012) ("Unless the articles provide otherwise, the board may issue shares, options or securities having conversion or option rights without first offering them to shareholders of any class.”); DEL. CODE ANN. tit. 8, $\S 102(b)(3)$ (West $2001 \&$ Supp. 2010) (providing no separate rule or exception for preemptive rights, but providing that the certificate of incorporation may contain provisions granting such rights).

216. But see N.Y. BuS. CORP. LAW § 622(e) (McKinney 2003) (listing types of securities or shares not subject to preemptive rights, unless otherwise provided for in the certificate of incorporation, and including shares "to be issued to satisfy conversion or option rights theretofore granted by the corporation"). 
In Delaware, preemptive rights are not granted upon the issuance or conversion of convertible securities unless the certificate of incorporation specifically grants such rights. ${ }^{217}$ However, if the certificate contains such an anti-dilution provision and the provision is ambiguous, it may be construed against the corporation. ${ }^{218}$ Thus, any anti-dilution provision should be provided for in the certificate of incorporation and should be as clear as possible.

In most jurisdictions, the default rule for shareholder voting is one share/one vote. ${ }^{219}$ Delaware law allows for alternative voting arrangements provided the corporate charter initially permits them or was amended accordingly. ${ }^{220}$ Delaware courts generally allow controlling shareholders to

217. Del. Code AnN. tit. 8, § 102(b)(3).

218. See Kaiser Aluminum Corp. v. Matheson, 681 A.2d 392, 399 (Del. 1996) (affirming the chancery court's injunction preventing the corporation from unilaterally changing the conversion rights of "Preferred Redeemable Increased Dividend Equity Securities" issued by the corporation to the plaintiffs). In that case, the shareholders sought to enjoin the defendant corporation from amending its certificate of incorporation to include a recapitalization plan that would convert preferred stock into common stock. Id. at 393. The corporation sought to amend the certificate and recapitalize without a vote of the preferred shareholders. Id. In holding that the existing conversion rights of the preferred stockholders should be construed to require conversion to the common stock existing before recapitalization, the court reasoned that the conversion rights stated in the certificate were ambiguous. Id. at 399.

219. DeL. Code ANN. tit. 8, § 212 (West 2006). Variations from one share/one vote can take several different forms. A common variation is when a corporation is initially incorporated with multiple classes of stock with disparate voting rights. The shares with enhanced voting rights are retained by insiders to ensure future control of the company. See Joel Seligman, Equal Protection in Shareholder Voting Rights: The One Common Share, One Vote Controversy, 54 GEO. WASH. L. REV. 687, 687-88 (1986). Another variation is a time-phased voting plan. Under a time-phased voting plan, the number of votes a shareholder can cast per share is dependent upon how long the shareholder has held his or her shares. Shareholders who have held their shares longer receive more votes. See Williams v. Geier, 671 A.2d 1368, 1380-81 (Del. 1996) (allowing time-phased voting where individuals holding shares for three years or more may cast ten votes per share). Another variation is a limit on the number of shares a single individual may vote. See Providence \& Worcester Co. v. Baker, 378 A.2d 121, 124 (Del. 1977) (upholding charter provision that caps the number of shares an individual shareholder may vote).

220. DeL. CodE ANN. tit. 8, §§ 151, 242 (West 2006). Section 151(a) empowers corporations to issue multiple classes of stock with disparate voting rights. Id. § 151. It also allows voting rights to be contingent on outside events. Id. Section 242(a) empowers a corporation to make "a change in stock or the rights of the stockholders" provided that a process in subsection (b), requiring both director and shareholder approval, is followed. Id. § 242; see also Williams, 671 A.2d at 1380-1381 (allowing time-phased voting where individuals holding shares for three years or more may cast ten votes per share); Baker, 378 A.2d at 124 (upholding charter provision that caps the number of shares an individual shareholder may vote); Weiss v. Rockwell Int'l Corp., No. 8811, 1989 WL 80345 , at *3 (Del. Ch. July 19, 1989) (dismissing claim of violation of fiduciary duties by directors for submitting amendment to shareholder vote that would authorize issue of super-voting stock). Commentators have also described the relative freedom Delaware law provides in determining the organization of corporations. See Edward P. Welch \& Robert S. Saunders, Freedom and Its Limits in the Delaware General Corporation Law, 
increase the voting rights of stock. ${ }^{221}$ Voting rights increases are limited if the increase is inequitable or would violate the fiduciary responsibilities of the directors and majority shareholders. ${ }^{222}$ Increasing the voting rights of contingent capital holders before resolution of a financial institution can create disparate voting rights between shareholders. ${ }^{223}$ This disparity between shareholders could set the right incentive for shareholders and management as proposed herein.

Dual-class voting rights may be created by several different mechanisms. $^{224}$ Dual-class voting rights can be implemented if the corporate charter initially provided for dual-class rights or was amended to provide for dual-class rights. If the charter requirement is satisfied, dual-class voting rights may be created through an initial public offering, a new public offering, a voting rights alteration, a special distribution, or an exchange offer. ${ }^{225}$

Delaware law supports the creation of super-voting $\operatorname{stock}^{226}$ if the increase in voting power serves the legitimate business purpose of

33 DEL. J. CORP. L. 845, 847-55 (2008) (describing how Delaware corporate law currently represents a broadly enabling freedom of contract norm).

221. See Benihana of Tokyo, Inc. v. Benihana, Inc., 891 A.2d 150, 170, 190 (Del. Ch. 2005) (holding that the corporation was authorized to issue preferred stock with preemptive rights based on the certificate of incorporation), aff'd, 906 A.2d 114 (Del. 2006); Williams, 671 A.2d at 1380-81; Wis. Inv. Bd. v. Peerless Sys. Corp., No. Civ. A. 17637, 2000 WL 1805376, at *9 (Del. Ch. 2000) (holding that "[i]n the absence of finding that the primary purpose of the board's action was to interfere with or impede exercise of the shareholder franchise, the business judgment rule presumption applies" (citing Williams, 671 A.2d at 1376)); Weiss, 1989 WL 80345, at *3 (dismissing claim of violation of fiduciary duties by directors for submitting amendment to shareholder vote that would authorize issue of super-voting stock).

222. See Schnell v. Chris-Craft Indus., Inc., 285 A.2d 437, 439-40 (Del. 1971) (holding that although board's inequitable attempt to perpetuate itself in office using the corporate machinery was legally possible, it was impermissible); Lacos Land Co. v. Arden Grp., Inc., 517 A.2d 271, 273, 278 (Del. Ch. 1986) (holding that an attempt to create a class of super-voting stock giving control of the company to CEO was inequitable because it was motivated by personal interest in gaining sole control of the company and accomplished through use of misleading statements and threats).

223. Douglas C. Ashton, Revisiting Dual-Class Stock, 68 St. John’s L. Rev. 863, 865-66 (1994).

224. See id. at 876-84; Jeffrey N. Gordon, Ties That Bond: Dual Class Common Stock and the Problem of Shareholder Choice, 76 CAL. L. REV. 1, 40-42 (1988) (describing the mechanisms through which dual-class stock is created in corporations that are already capitalized-exchange offers, special distributions, and voting rights alterations).

225. See Ashton, supra note 223, at 876-84 (describing five different mechanisms by which dual-class stock is created).

226. Williams, 671 A.2d at 1372 (allowing "tenure voting” system, which would give shareholders of three years ten times more votes than shareholders of less than three 
preserving the financial institution as it approaches insolvency or dissolution. ${ }^{227}$ Allocating super-voting stock, as proposed herein, would be for the legitimate business purpose of avoiding both insolvency and dissolution. Historically, stock exchanges in the United States have limited the ability of listed corporations to issue stock that would dilute the voting rights of existing shareholders. ${ }^{228}$ The SEC had promulgated regulations restricting voting rights increases that diluted existing shareholders' voting rights. ${ }^{229}$ However, courts invalidated these rules. ${ }^{230}$ Despite the invalidation of SEC restrictions, stock exchanges have independently continued to apply a uniform voting rights policy restricting voting rights increases. ${ }^{231}$ The policy allows for dual-class capitalization but prohibits midstream changes in voting rights if voting rights of other classes of stock are diluted. ${ }^{232}$ However, there is no absolute ban on supervoting stock. The NYSE and Nasdaq policies are subject to several exemptions. ${ }^{233}$ Although the policies may restrict the voting rights

years); Weiss, 1989 WL 80345, at *3 (dismissing claim of violation of fiduciary duties by directors for submitting amendment to shareholder vote that would have authorized issue of super-voting stock).

227. Williams, 671 A.2d at 1377-78 (applying the business judgment rule to action of board in recommending charter amendment altering voting rights of stock).

228. See Arthur Fleischer, Jr. \& Alexander R. SusSman, TAKeOVER Defense: MERGERS AND ACQUISITIONS $\S 6.04$ (6th ed. Supp. 2012)

229. See 17 C.F.R. \& 240.19c-4 (2011). Rule 19c-4 was issued under authority granted to the SEC by the Securities and Exchange Act of 1934. The rule was accompanied by an SEC release elaborating on the background and intended effect of the rule. See Securities Exchange Act of 1934: Voting Rights Listing Standards-Disenfranchisement Rule, 41 SEC Docket (CCH) No. 34-25891, at 432 (July 7, 1988).

230. See, e.g., Bus. Roundtable v. SEC, 905 F.2d 406, 407, 417 (D.C. Cir. 1990) (holding that the SEC exceeded its statutory authority in creating a rule regulating the substantive allocation of powers among classes of shareholders).

231. See Section 3 Corporate Responsibility, NYSE LISTED COMPANY MANUAL, http://nysemanual.nyse.com/LCM/Sections (last visited Mar. 4, 2012) (restricting, in section 313.00(A), voting rights increases); see also Securities and Exchange Act of 1934: Order Granting Approval to Rule Changes Relating to the Exchanges' and Association's Rules Relating to Shareholder Voting Rights, 58 SEC Docket (CCH) No. 34-35121, at 1179 (Dec. 19, 1994) (approving amendments to the listing standards of the NYSE, AMEX, and NASD that established a uniform voting rights policy across all of the exchanges); NASDAQ Stock Market Rules: Equity Rule 5640, NASDAQ (Mar. 12, 2009), http:// nasdaq.cchwallstreet.com/.

232. Stock with disparate voting rights may still be issued in an initial public offering. See infra text accompanying note 233.

233. Although the uniform voting policy itself is contained in a single paragraph in each exchange's listing standards, the exchanges have issued interpretations clarifying the policy. Frequently Asked Questions: Listing Qualifications-Corporate Governance, NASDAQ OMX LISTING CTR., https://listingcenter.nasdaqomx.com/Show_Doc.aspx? File=FAQsCorpGov.html (last visited Mar. 4, 2012) (discussing voting rights). In addition, the initial notice accompanying the SEC approval of the Uniform Voting Policy stated that issues of stock that would have fallen under exceptions included in the invalidated Rule 19c-4 would still be allowed under the new policy. See Securities and Exchange Act of 1934: Notice of Filing of Proposed Rule Changes Relating to the Exchanges' and 
increase proposed herein, we believe these restrictions should not be applied to CCS. NYSE and Nasdaq would benefit from exempting CCS from their respective policies because an exemption from the policies could increase the marketability and the trading on each exchange.

The voting rights increase could change the corporate governance of the corporation before resolution and could increase the influence of activist shareholders. The role of shareholders in corporate governance is the subject of a long academic debate. ${ }^{234}$ Although we believe this debate is important and helps determine the optimal design of corporate governance in the United States, the proposal in this Article would give rise to additional voting rights and add to shareholder influence only if conversion of CCS did not provide a sufficient equity capital injection to return the company to financial viability. The second trigger voting rights increase should never actually be triggered. Rather, it should help level the playing field between constituents and incentivize negotiation and provide an alternative to reorganization. ${ }^{235}$

\section{CONSTITUENT INCENTIVES}

Contingent capital is primarily intended as a supplement to higher capital and liquidity requirements and a measure to increase loss absorbency of financial institutions. Contingent capital securities can also provide

Association's Shareholder Voting Rights, 57 SEC Docket (CCH) No. 34-34518, at 912 (Aug. 11, 1994). The four exceptions are: (1) dual-class securities issued in an initial public offering, (2) issuance of a new class of securities with voting rights no greater than an existing class of security, (3) issuance of stock with voting rights no greater than any outstanding class to effect a merger or acquisition, (4) corporate action taken to comply with state mandatory control-share statutes. 17 C.F.R. § 240.19c-4(d)(1)-(4) (2011).

234. See Stephen M. Bainbridge, The Case for Limited Shareholder Voting Rights, 53 UCLA L. REV. 601, 636 (2006); Lucian Arye Bebchuk, The Case for Increasing Shareholder Power, 118 HARV. L. ReV. 833 (2005); Roberta Romano, Less Is More: Making Institutional Investor Activism a Valuable Mechanism of Corporate Governance, 18 Yale J. ON REg. 174, 231-32 (2001). But see Iman Anabtawi, Some Skepticism About Increasing Shareholder Power, 53 UCLA L. REV. 561 (2006); Stephen M. Bainbridge, Director Primacy and Shareholder Disempowerment, 119 HARV. L. REV. 1735 (2006); Lucian A. Bebchuk, The Myth of the Shareholder Franchise, 93 VA. L. REV. 675 (2007); William W. Bratton \& Michael L. Wachter, The Case Against Shareholder Empowerment, 158 U. PA. L. REV. 653 (2010); Paramount Commc'ns Inc. v. Time Inc., Nos. 10866, 10670, 10935, 1989 WL 79880, at *30 (Del. Ch. 1989), aff'd, 571 A.2d 1140 (Del. 1990); Leo E. Strine, Jr., Toward a True Corporate Republic: A Traditionalist Response to Bebchuk's Solution for Improving Corporate America, 119 HARV. L. ReV. 1759 (2006); Julian Velasco, Taking Shareholder Rights Seriously, 41

U.C. DAVIS L. REV. 605 (2007).

235. See infra Part V. 
incentives to lower risk. To avoid signaling default risk, CCS can incentivize a voluntary increase of capital well in advance of a possible default. These incentives are important because they make it possible for the institution to use contingent capital as a self-policing and checks-andbalances device. Contingent capital is meant to prevent incentives for excessive risk-taking and remedy the reliance on public bailouts. Under a contingent capital regime, management, shareholders, and creditors are similarly affected because the conversion feature can change the power, dependency, and perhaps even the control dynamic in the company. In this capacity, CCS could help fill the void left by regulators' inability to supervise financial institutions effectively, often the result of insufficient public funding.

Increased voting rights could make CCS more effective by adding an additional incentive. The real possibility of increased dilution plus loss of corporate governance could work as an effective incentive to lower risk or force the increase of capital before the company files for bankruptcy. The second trigger, as proposed here, would increase the dilutive effect of conversion with a possible threat of change of control, namely, a majority shareholder could lose control over the entity, provided all CCS holders vote in unity, have support from some incumbent shareholders, or both. This could change the corporate governance dynamic of the corporation in many ways.

The voting rights trigger could influence a quorum, or lack thereof, to call a meeting or a quorum to vote on action items at company meetings. This may not only be significant in the context of supporting incumbent management but also force a vote on new management to change the course of the company, restructure, or discharge assets. A quorum may also allow for changes in bonuses or executive salaries. Changing the power structure within the company at such a crucial moment in the history of the company-facing resolution — could increase constituents' incentives to avoid the change in power dynamics by taking appropriate precautions.

Increased voting rights of CCS holders could provide a level of independence for management. Under this regime of contingent capital, management could be more conservative in the day-to-day operations of the company without fear that if management personnel do not take the expected level of risk, often induced by shareholders, they will lose their job. At the same time, increased voting rights could also magnify management accountability because CCS holders combined with other interested (institutional) shareholders could be in a position to demand corrective action before reorganization or remove management swiftly. No creditor really wants to be an equity holder if the company cannot pay its financial obligations. 
For management, operating effectively in an environment of contingent capital regimes could largely depend on whether it puts its fate into the hands of incumbent shareholders or the new CCS holders who hold at least a quorum. If incumbent management has the support of CCS holders, a sufficient fraction of incumbent shareholders to form a quorum, or both, incumbent management may be able to get important decisions approved by the board before reorganization.

How influential CCS holders could be may depend to some extent on the degree of mandatory CCS issuance. Although the EU Commission estimates between four and nineteen percent of risk-weighted assets, ${ }^{236}$ Goldman Sachs suggests the mandatory issuance requirement could be in the vicinity of four to eight percent of risk-weighted assets. ${ }^{237}$ Even at the lower end of these estimates, the increase in voting rights would have to be substantial to result in a change in corporate control of a SIFI. Whether that could have an impact on pricing and marketability remains to be seen. ${ }^{238}$

Although there is a risk that a CCS conversion could be triggered, especially if the trigger design was suboptimally designed, both contractually or by a regulator, we would expect that voting rights increases by way of a second trigger would be rare because management and incumbent shareholders are incentivized to avoid a triggering event. However, to be effective, the level of a possible voting rights increase should probably be substantial enough to incentivize the avoidance of the triggering event. It should provide the constituents with the right incentives to negotiate in a quasi-preparation stage before reorganization or bankruptcy proceedings. The second trigger is also unlikely to be triggered accidentally or for non-systemic reasons because the stakes are much higher for all constituents, which further incentivizes finding a privately negotiated solution.

236. DG WORKING DOCUMENT, supra note 8, Annex I, at 89 n.24.

237. GoldMAN SACHS GlOBAL MKTS. INST., supra note 29, at 13.

238. The increase in voting rights could create marketability issues for CCS because the increase in voting rights could increase the cost of the CCS. Issuers that are subject to mandatory CCS issuance rules may demand a premium if the CCS have a second trigger with a (substantial) voting rights increase. Especially if the voting rights increase could reach the level of change of control over the entity, the premium charged by the issuers could rise dramatically and could result in a primary issuance to institutional investors who have an interest in the change of control possibility. Whether other factors can offset this and increase the marketability is unclear. 


\section{QUASI-PREPARATION STAGE BEFORE BANKRUPTCY}

Contingent capital could have a variety of applications before and during bankruptcy proceedings. Although the reorganization procedure under Chapter 11 is currently not applicable to banks in the United States, ${ }^{239}$ many European countries have enacted similar reorganization procedures for financial institutions. ${ }^{240}$ In the context of these procedures, CCS could work as effective supplements for insolvency proceedings. ${ }^{241}$ Contingent capital securities could further integrate bank resolution proposals focusing on corporate restructuring with proposals that focus on liquidation through bankruptcy proceedings.

A specific advantage of contingent capital is its ability to create an opportunity for holders of contingent capital and former creditors to participate in the reorganization of the financial institution at a much earlier stage, pre-bankruptcy. In addition, in European jurisdictions that introduced a reorganization procedure similar to Chapter 11 , such as Germany, ${ }^{242}$ CCS could offer the added advantage of pre-negotiated or prepackaged plans common in the United States. ${ }^{243}$ This could help accelerate reorganization procedures and could entail a forty-eight to ninetysix hour stay on termination rights of derivative contracts. ${ }^{244}$

Perhaps one of the biggest advantages of contingent capital is its ability to involve shareholders directly. Shareholders can participate in the issuance of CCS and are in a position to consider the risk of default at a much earlier stage. Shareholders have the possibility, prior to each triggering event, to influence corporate governance and to prevent dilution or additional loss of voting rights. They may replace management and can vote on major corporate policy changes, such as abandoning a

239. 11 U.S.C. § 109(b)(2) (2006).

240. See Henkel \& Kaal, supra note 57.

241. SKEEL, supra note 3, at 84.

242. KREDitinstitute-REORGANIZATIONSGESETZ [KredREORG] [FinANCIAL Institution ReORganization Act], Dec. 9, 2010, BGBL. I at 1900, §§ 7-23 (Ger.) (including the requirement of a reorganization plan approved by creditors' committees).

243. See, e.g., In re Pioneer Fin. Corp., 246 B.R. 626, 630 (Bankr. D. Nev. 2000) (describing prepackaged and pre-negotiated plans); Chelsea Emery, Reader's Digest Plans To File for Chapter 11 Bankruptcy, REUTERS, Aug. 19, 2009, available at 2009 WLNR 16170098.

244. The stay on termination rights of derivative contracts is already available under German law and was suggested for bankruptcy reform in the United States. See SkEEL, supra note 3, at 59, 159. Under Dodd-Frank parties to qualified financial contracts or "QFCs" may not exercise any right to terminate until the earlier of (1) the time at which the person has received notice that the QFC has been transferred or (2) 5:00 p.m. eastern time on the business day following the date of the appointment of the FDIC as receiver. 12 U.S.C. § 5390(c)(8)(F)(ii) (2006). QFCs are defined as securities contracts, commodity contracts, forward contracts, repurchase agreements, swap agreements, and other similar agreements. Id. § 5390(c)(8)(D)(i). 
certain business segment or implementing measures that would otherwise be prescribed by the supervising authority. ${ }^{245}$ Even after the conversion of debt to equity following the first triggering event, shareholders have an incentive to work closely with CCS holders to prevent further deterioration of the institution and to prevent CCS holders from gaining control over the institution. Finally, even after the second trigger and the resulting increase in voting rights, incumbent shareholders and new CCS shareholders can influence the direction of the institution and avoid liquidation.

In sum, CCS offer a reorganization option in a system focused on liquidation but also create a mechanism that is more efficient, less expensive, and less time consuming than a reorganization procedure under Chapter 11. Strategic maneuvering of creditors prior to filing for bankruptcy protection or during the negotiations leading up to plan confirmation could distort the herein-proposed incentives for constituents. Strategic maneuvering could play an equally important role at the stage of CCS conversion and the increase of voting rights. The benefits of the proposal in this Article could, however, outweigh the risk associated with strategic behavior. This also applies to possible challenges by shareholders over conversion and the trigger to increase voting rights. Transaction and social costs associated with our proposal, among others, will require additional research.

In addition to the described incentives and quasi-preparation stage before bankruptcy, contingent capital also combines other bankruptcy elements, such as the concept of a debtor in possession (DIP) or creditors' committees. Contingent capital in the context of developing a time-efficient reorganization procedure for banks resembles the discussion of "chameleon equity" in the late 1980s and early 1990s. ${ }^{246}$

\section{A. Debtor in Possession and Creditors' Committees}

Under U.S. bankruptcy law, insurance companies and banks are not eligible to file under Chapter $11 .^{247}$ The comparison between CCS and

245. See Council Directive 2006/48, art. 136, 2006-2010 O.J. (L 177) 1 (EU); European COMM'N SERVs. STAFF, COMMISSION SERVICES STAFF WORKING DOCUMENT: Possible FurTher Changes to the CAPITAL ReQuiREMENTS DiReCTIVE 1-2 (2010), http:// ec.europa.eu/internal_market/consultations/docs/2010/crd4/consultation_paper_en.pdf.

246. See Adler, supra note 17, at 323-33; see also Skeel, supra note 18, at 483 (expanding on Adler's discussion of chameleon equity).

247. 11 U.S.C. $\S 109(d)(2006)$. 
concepts of Chapter 11 helps underscore the advantages of CCS that are similar to the reorganization procedure under Chapter 11 . It shows that contingent capital can work as a quasi-preparation stage for reorganization or even liquidation. Moreover, legislators in Europe have clearly incorporated many aspects of Chapter 11 into their national bank reorganization and resolution laws, offering an alternative to liquidation. ${ }^{248}$ The advantages of Chapter 11, in particular with regard to prearranged, pre-negotiated, and prepackaged bankruptcy cases, ${ }^{249}$ could further improve European bank reorganization and resolution procedures. ${ }^{250}$

Under U.S. bankruptcy law, the filing of a Chapter 11 case generally institutes a DIP. ${ }^{251}$ It is therefore the norm that the debtor, and not an independent trustee, oversees the reorganization procedure under U.S. law. ${ }^{252}$ The DIP is recognized as a hybrid creature who is the "debtor except when [he or she] ... is serving as trustee"253 and who therefore assumes two functions: (1) as debtor qua debtor ${ }^{254}$ and (2) as debtor qua trustee. ${ }^{255}$ The purpose of installing a DIP is to create consistency when operating a business as a going concern under Chapter 11. It is assumed that the debtor and incumbent management of businesses filing for protection under Chapter 11 know their organization and are best positioned to return a corporation to profitability. After all, the central premise of any reorganization procedure is to permit financially interested parties to capture the going concern value of the debtor's business and to prevent parceling out assets. ${ }^{256}$

The reasoning behind the concept of DIP can also be applied to troubled financial institutions by comparing a financial institution after the conversion of CCS into equity with a corporation entering reorganization. Especially at a stage where a bank is in distress and where timeliness is

248. See Henkel \& Kaal, supra note 57.

249. See In re Pioneer Fin. Corp., 246 B.R. 626, 630 (Bankr. D. Nev. 2000) (describing prepackaged and pre-negotiated plans); CHARLES JORDAN TABB, THE LAW OF BANKRUPTCY 1130 (2d ed. 2009); Emery, supra note 243.

250. A good example is the German bank reorganization procedure. See Henkel \& Kaal, supra note 57 . A prearranged reorganization after CCS conversion may make the stay on termination rights of derivative contracts of up to ninety-six hours more effective than under current law. A reorganization plan may be in place before the stay terminates, and contract parties of derivative contracts may thus be forced to also share in potential losses.

251. TABB, supra note 249 , at 1053-54.

252. An independent trustee may be appointed by the court if the requisite requirements of the U.S. Bankruptcy Code, 11 U.S.C. § 1104 (2006 \& Supp. IV 2011), are fulfilled.

253. Id. § 1101(1).

254. TABB, supra note 249, at 1054; see Daniel B. Bogart, Liability of Directors of Chapter 11 Debtors in Possession: “Don't Look Back—Something May Be Gaining on You,” 68 AM. BANKR. L.J. 155 (1994).

255. TABB, supra note 249, at 1054.

256. Id. 
of the essence, incumbent management can provide the needed consistency to realize the value of the institution as a going concern. Just as an independent trustee in bankruptcy, ${ }^{257}$ new management would need to familiarize itself with the corporation before being able to effectively make necessary, and often difficult, decisions. CCS holders as former creditors will have a natural interest in consistency. It is their main interest to realize their claims. CCS holders are therefore likely to support incumbent management. CCS holders' perhaps changing perspective as equity holders after the conversion should not change their interest in consistency. CCS investors may generally be interested not in becoming equity holders but rather in recouping their investment or collecting on their claims. True to the hybrid character of the DIP as "debtor qua trustee," management accountability may also be increased after the debtequity conversion and as it relates to CCS holders. Assuming CCS holders support incumbent management and management depends on their vote to stay in office, it is likely that incumbent management will also protect

257. An independent trustee will be appointed only if the requirements of U.S. Bankruptcy Code § 1104(a)(1)-(3) are fulfilled. House Report No. 95-595 gives the justification of and the reason for the debtor in possession:

[V]ery often the creditors will be benefited by the continuation of the debtor in possession, both because the expense of a trustee will not be required, and the debtor, who is familiar with his business, will be better able to operate it during the reorganization case. A trustee frequently has to take time to familiarize himself with the business before the reorganization can get under way. Thus, a debtor continued in possession may lead to a greater likelihood of success in the reorganization. Moreover, the need for reorganization of a public company today often results from single business reverses, not from any fraud, dishonesty, or gross mismanagement on the part of the debtor's management. Even if the cause is fraud or dishonesty, very frequently the fraudulent management will have been ousted shortly before the filing of the reorganization case, and the new management, very capable of running the business, should not be ousted by a trustee because of the sins of former management. ...

... [F]acilitation of the reorganization to the benefit of the debtor and the creditors[] militates against the appointment of a trustee. ... Debtors' lawyers that participated in the development of a standard for the appointment of a trustee were adamant that a standard that led to too frequent appointments would prevent debtors from seeking relief under the reorganization chapter, and would leave the chapter largely unused except for extreme cases. One of the problems that the Bankruptcy Commission recognized in current bankruptcy and reorganization practice is that debtors too often wait too long to seek bankruptcy relief. Too frequent appointment of a trustee would exacerbate that problem, to the detriment of both debtors and their creditors.

H.R. REP. NO. 95-595, at 233-34 (1977) (citation omitted), reprinted in 1978 U.S.C.C.A.N. 5963, 6192-93. 
CCS holders' interests, not unlike the fiduciary duties a DIP has to the bankruptcy estate.

Creditors' committees also play a prominent role in Chapter 11 cases. $^{258}$ Under $\S 1103,{ }^{259}$ creditors' committees have supervisory and investigatory powers and participate in the formulation of the reorganization plan. ${ }^{260}$ Applying this to CCS conversion, CCS holders with increased voting rights will have similar powers and may even hold the equivalent of a veto right. The proposal in this Article would, however, create a far more flexible and efficient solution than Chapter 11. Neither court involvement nor a threshold of creditor approval would be required. In addition, like prearranged or prepackaged plans in the United States, ${ }^{261}$ the quasipreparation stage for reorganization after CCS conversion could provide a more efficient procedure in achieving plan approval and confirmation. Finally, given the focus on orderly liquidation and winddown of the financial institution in the Dodd-Frank Act, ${ }^{262}$ the stage after conversion and before liquidation may be the last chance for CCS holders as former creditors to "secure" their debt in the United States.

The proposal in this Article has the advantage of an early involvement of creditors even before any possible bankruptcy proceedings, with the added bonus of management consistency and accountability. Both of these advantages could make dual trigger CCS as proposed herein more marketable and create overall lower risk while keeping regulatory prompt corrective actions and liquidations at bay. In fact, the issuance of a dual trigger CCS as proposed herein provides an option similar to a reorganization procedure and may allow a distressed financial institution to return to profitability. In sum, this should further increase the chances that this form of CCS will be rated. Conversion and voting rights increases are predictable and not dependent on regulatory action.

\section{B. Contingent Capital in Prepackaged Bankruptcy Plans and Preplan Sales}

Contingent capital may offer a preferable alternative to out-of-court workout agreements by reducing uncertainties and improving efficiency.

\footnotetext{
258. 11 U.S.C. § 1103 (2006).

259. Id.

260. Id. § 1103(c); see also TABB, supra note 249, at 1066-67.

261. Id. §§ 1125(g), 1126(b); In re Pioneer Fin. Corp., 246 B.R. 626, 630 (Bankr. D. Nev. 2000) (describing prepackaged and pre-negotiated plans); TABB, supra note 249, at 1130 .

262. Dodd-Frank Wall Street Reform and Consumer Protection Act § 214, 12 U.S.C. $\S 5394$ (Supp. IV 2010).
} 
Using CCS could have advantages over prepackaged bankruptcy plans ${ }^{263}$ and preplan sales. ${ }^{264}$ Prepackaged plans and preplan sales are common practice in reorganizations under Chapter 11. These arrangements are generally considered to be more flexible and faster alternatives to ordinary Chapter 11 confirmation proceedings. ${ }^{265}$ Although prepackaged plans may be initiated by obtaining the creditors' agreement to a plan prior to any bankruptcy petition, ${ }^{266}$ preplan sales may be executed only during the pendency of a case or as part of a reorganization plan under Chapter $11 .^{267}$

An advantage of prepackaged plans is the shorter time period in which a reorganization plan can be confirmed. ${ }^{268}$ In contrast with the lengthy confirmation procedure of a reorganization plan under ordinary Chapter 11 proceedings, the acceptance obtained from creditors under prepackaged plans can be used to confirm the plan following the bankruptcy petition with the additional advantage of binding any dissenting creditor. $^{269}$ Prearranged plans work similarly. ${ }^{270}$ The most significant downside of prepackaged plans is the risk that disclosure requirements and other safeguards under the Bankruptcy Code are short circuited, thereby violating creditors' rights. ${ }^{271}$ The Bankruptcy Code addresses this problem by prescribing that solicitation and disclosure of prepackaged plans must provide adequate information. ${ }^{272}$ The Code does not define the parameters

263. Brian K. Tester et al., Need for Speed: Prepackaged and Prenegotiated Bankruptcy Plans, Bus. Reorganization (Am. Bankr. Inst., Alexandria, VA.), June 2010, at 399, available at http://www.abiworld.org/committees/newsletters/busreorg/vol9num7/pack.pdf.

264. William T. Bodoh et al., The Parameters of the Non-Plan Liquidating Chapter 11: Refining the Lionel Standard, 9 BANKR. DEV. J. 1, 3 (1992).

265. See also Thomas H. Jackson, Chapter 11F: A Proposal for the Use of Bankruptcy To Resolve Financial Institutions, in ENDING GOVERNMENT BAILOUTS 217 (Kenneth E. Scott et al. eds., Stanford Univ. Press 2009), available at http://media. hoover.org/sites/default/files/documents/Ending_Government_Bailouts_as_We_Know_Them 217.pdf; Edward R. Morrison, Is the Bankruptcy Code an Adequate Mechanism for Resolving the Distress of Systemically Important Institutions?, 82 TEMP. L. REV. 449 (2009); Rodgin Cohen \& Morris Goldstein, The Case for an Orderly Resolution Regime for Systemically-Important Financial Institutions (Peterson Inst. for Int'l Econ. Pew Charitable Trusts, Briefing Paper No. 13, 2009), available at http://www.iie.com/publications/papers/ goldstein1009.pdf.

266. See, e.g., In re Papercraft Corp., 187 B.R. 486 (Bankr. W.D. Pa. 1995).

267. 11 U.S.C. § 363 (2006).

268. Charles J. Tabb, The Future of Chapter 11, 44 S.C. L. REv. 791, 848 (1993).

269. 11 U.S.C. § 1141 (2006).

270. Id. §§ 1125(g), 1126(b); see also TABB, supra note 249, at 1130 . For a more comprehensive discussion, see Tabb, supra note 268, at 848-50.

271. In re Southland Corp., 124 B.R. 211, 225 (Bankr. N.D. Tex. 1991).

272. 11 U.S.C. $\S 1126(b)$ (2006). 
or meaning of the term adequate. Prepackaged plans therefore run the risk of providing inadequate information. ${ }^{273}$ Given this shortcoming, the agreement may be challenged by creditors. In many cases, the prepetition votes cannot be utilized, forcing the reorganization into the ordinary and much longer plan confirmation procedure under Chapter 11. Prepetition agreement in prepackaged plans must conform to nonbankruptcy disclosure laws, which may be stricter than those required under Chapter 11 itself. $^{274}$ Finally, it is questionable whether prepackaged plans may always be the best option for the reorganization of financial institutions or financial holding companies that require complex debt restructuring, including derivative contract termination and asset selloffs. $^{275}$

Preplan sales under $\S 363$ of the U.S. Bankruptcy Code ${ }^{276}$ face similar concerns. A preplan sale effectively ends the bankruptcy case without protecting creditors under the confirmation procedure of Chapter $11 .^{277}$ A preplan sale thus has the "practical effect of dictating some of the terms of any future reorganization plan." ${ }^{278}$ Courts disagree on the timing and appropriateness of preplan sale approvals. Although some courts require a genuine emergency, ${ }^{279}$ a majority of courts permit sale approval based on the business judgment standard or where the sale proponents offer a "good business reason" for the sale. ${ }^{280}$ However, the consensus among courts seems to be that preplan sales may not be approved if doing so may generally conflict with the protection of creditors or attempts to provide a more effective reorganization procedure. ${ }^{281}$ The Fifth Circuit has been the most outspoken and noted that "the debtor and the Bankruptcy Court should not be able to short circuit the requirements of Chapter 11 for confirmation of a reorganization plan by establishing the terms of the plan sub rosa in connection with a sale of assets."282 Thus,

273. Douglas M. Foley \& James E. Van Horn, Prepacks on the Rise in Chapter 11 Bankruptcies Prenegotiated Plans Can Accelerate Reorganizations, TMA (Aug. 27, 2008), http://www.turnaround.org/Publications/Articles.aspx?objectId=9655 (stating that "[e]ven if a debtor obtains the requisite number of acceptances for its prepackaged Chapter 11 plan, the risk remains that a Bankruptcy Court ultimately may rule that the debtor's pre-petition solicitation and/or disclosure statements were not 'adequate' under [the] Bankruptcy Code").

274. See, e.g., TABB, supra note 249, at 1131.

275. Id. at $1131-32$.

276. 11 U.S.C. $\S 363(b)$, (c) (2006).

277. In re White Motor Credit Corp., 14 B.R. 584, 590 (Bankr. N.D. Ohio 1981).

278. In re Braniff Airways, Inc., 700 F.2d 935, 940 (5th Cir. 1983).

279. See, e.g., White Motor Credit Corp., 14 B.R. at 588.

280. See, e.g., In re Lionel Corp., 722 F.2d 1063, 1071 (2d Cir. 1983).

281. See, e.g., Fla. Dep’t of Revenue v. Piccadilly Cafeterias, Inc., 554 U.S. 33 (2008).

282. Braniff Airways, Inc., 700 F.2d at 940. 
a major concern of preplan sales is whether the sale is a disguised reorganization with the explicit or implied intent of preempting creditors' rights.

Moreover, although preplan sales under $\S 363$ are faster and more flexible than Chapter 11 plan confirmation, a sale out of the ordinary course of business may be approved only "after notice and a hearing."283 Although the Bankruptcy Rules ${ }^{284}$ follow a negative notice approach for preplan sales in this context, ${ }^{285}$ creditors may always request a hearing and must be provided with a twenty-one-day notice of such sale. ${ }^{286}$ Although courts can shorten this period, ${ }^{287}$ an appeal of the bankruptcy court's order could further delay the preplan sale. ${ }^{288}$

The use of CCS could help avoid some of these challenges. Compared with prepackaged resolution plans or preplan sales, CCS in a quasipreparation stage for bankruptcy could provide a more efficient procedure for reorganization. More specifically, CCS could be more efficient because CCS could provide the basis for a resolution mechanism outside of formal resolution proceedings and without the restrictions of prepackaged plans or preplan sales. The Bankruptcy Code does not regulate CCS conversion or the use of increased voting rights. Contingent capital securities are, for the most part, privately negotiated contracts. ${ }^{289}$

In the face of conversion of CCS into equity, a financial institution in distress may be able to convince outside creditors and unconverted CCS holders to agree to preapprove a reorganization plan. Outside creditors and CCS holders may generally be disinterested in becoming equity holders. $^{290}$ After CCS convert into equity, former CCS creditors (now

\footnotetext{
283. 11 U.S.C. § 363(b)(1) (2006).

284. FED. R. BANKR. P. (as amended May 1, 2010).

285. 11 U.S.C. § 102(1) (2006).

286. See FED. R. BANKR. P. 2002(a), 6003.

287. Id. 6004(c), 2002(c). In the Lehman Brothers' Chapter 11 case, the court held the preplan sales hearing and approved the sale of LBI's assets to Barclays in just five days after the filing of the Chapter 11 petition. See Robert J. Rosenberg et al., Bankruptcy 2010: Views from the Bench, Asset Sales (Am. Bankr. Inst., Alexandria, Va.), Oct. 2010, at 7, available at www.abiworld.org/committees/newsletters/assetsales/vol7num8/ issues.pdf.

288. See, e.g., Admin. Office of the U.S. Courts, Report Pursuant to Section 202(E) OF THE DODD-Frank WALl STREet REFORM AND CONSUMER PROTECTION ACT OF 2010, at 28 (2011).

289. See supra Part V.

290. Coffee, supra note 15, at 828, 836-37 (arguing that although several offerings of contingent capital have been successfully completed, they "hardly demonstrate that investors have definitively accepted this new product”); Anat R. Admati et al., Fallacies, Irrelevant
} 
equity holders) may still primarily be interested in realizing their initial investment and reducing their losses. Whether these converted equity holders would continue to favor pre-resolution agreements to sell or transfer assets seems less clear. However, pre-bankruptcy arrangements entered into after CCS conversion may not be as easily challenged in court as traditional prepackaged plans or preplan sales. In addition, a sale of assets may be entirely executed outside of or prior to any bankruptcy proceeding. Such sale could work like a bridge bank transfer ${ }^{291}$ or the sale to a private sector purchaser, ${ }^{292}$ except that, unlike a bridge bank or private sector transfer, ${ }^{293}$ the presale would be conducted outside of and not within resolution. ${ }^{294}$ Finally, a transfer or sale of assets outside of bankruptcy may also avoid the need of disclosing business information by the buyer or transferee to a large number of creditors that may otherwise be necessary for approval and confirmation in bankruptcy. ${ }^{295}$

Facts, and Myths in the Discussion of Capital Regulation: Why Bank Equity Is Not Expensive 53-55 (Stanford Graduate Sch. of Bus., Research Paper No. 2065, 2011), available at http://papers.ssrn.com/sol3/papers.cfm?abstract_id=1669704; Pennacchi, supra note 45; Sundaresan \& Wang, supra note 39, at 2; Investor Views on Contingent Capital, REUTERS, Oct. 18, 2010, available at http://www.reuters.com/article/2010/10/18/banks-capital-cocosinvestors-idUSLDE69D0QR20101018; see also Brett Goldblatt, Getting Out After It's Too Late: Exit Strategies in Chapter 11 Bankruptcies, 23 AM. BANKR. INST. J., Oct. 2004, at 26; Claire A. Hill, Why Financial Appearances Might Matter: An Explanation for "Dirty Pooling” and Some Other Types of Financial Cosmetics, 22 DEL. J. CoRP. L. 141, 16970 (1997) ("Debtholders generally know more about the company than do the stockholders. If they and the company are both willing to engage in the debt/equity swap, it seems likely that the debt has declined in value- that the debtholders doubt the company's ability to pay.”).

291. Note that under Dodd-Frank bridge banks are defined as "bridge financial companies." The FDIC has the authority to establish bridge financial companies in the context of conducting its liquidation responsibilities and may do so as part of an existing receivership or in anticipation of a receivership. The FDIC may transfer any assets and liabilities to one or more bridge financial companies. 12 U.S.C. $§ 5390(h)(5)(A)(2006)$. This is different from bridge bank models in Europe. For example, in Germany a bridge bank may be not only a corporation organized as a special purpose vehicle und public law and ownership but also any financial institution willing to participate in the rescue of a distressed bank. See, e.g., Henkel \& Kaal, supra note 57, at 36 \& n.420.

292. See, e.g., Banking Act, 2009, c. 1, § 11 (Eng.), available at http://www.legislation. gov.uk/ukpga/2009/1/pdfs/ukpga_20090001_en.pdf.

293. See supra note 291.

294. See supra note 291.

295. The asset sale or transfer to a bridge bank may always raise questions about valuation. See, e.g., 12 U.S.C. § 5390(h)(8)(B) (2006). This may be even more important where, as in Germany or the United Kingdom, a private sector purchaser may fulfill the role of the bridge bank. Particularly in Germany, a private sector purchaser or financial institution must give consideration to the distressed bank if the overall value of the transferred assets is positive. Any such consideration may include shares, which in turn would require significant disclosure in order to determine whether or not the consideration given is commensurate to the value of the transferred assets. See Henkel \& Kaal, supra note 57 , at 36 \& nn.417-26. 
How successful financial institutions may be in convincing outside creditors and unconverted CCS holders to approve a reorganization plan before bankruptcy could largely depend on the institution-specific volume of possible CCS conversion. Outside creditors and unconverted CCS holders may not always agree on a prepackaged or prearranged plan. For instance, if CCS holders acquired CCS with the intent to exercise control before or during bankruptcy, they could have a different perspective on reorganization plans than outside creditors. We recognize that these and other open issues merit additional research.

\section{Chameleon Equity}

The idea of using contingent capital in the context of corporate reorganization is not new. ${ }^{296}$ In bankruptcy theory, contingent capital is associated with the term chameleon equity ${ }^{297}$ and the old academic debate as to whether or not Chapter 11 should be abolished. ${ }^{298}$

Chameleon equity ${ }^{299}$ was the attempt to replace Chapter 11 with contingent capital by providing for the automatic cancellation of a corporation's stock in the event of any default. ${ }^{300}$ Professors Michael Bradley, Michael Rosenzweig, and others proposed this idea in the late 1980s and early 1990s. ${ }^{301}$ The idea was heavily criticized by Professors Elizabeth Warren and Lynn LoPucki ${ }^{302}$ and never went beyond the early draft proposals. ${ }^{303}$ Today, the majority view is pro-reorganization and can be best summarized with an oft-cited quotation: "[A] business is worth more alive than dead-i.e., it is worth more as a going concern than in a forced sale liquidation." ${ }^{\text {, }} 04$ We do not intend to revive the debate on chameleon equity or take a position on the merits of Chapter 11.

296. See also Baird, supra note 16, at 182; Scott, supra note 16, at 703-05.

297. Adler, supra note 17, at 323; see also Skeel, supra note 18, at 483.

298. See THOMAS H. JACKSON, THE LOGIC AND LIMITS OF BANKRUPTCY LAW 209-224

(1986); Douglas G. Baird, The Uneasy Case for Corporate Reorganization, 15 J. LEGAL STUDS. 127 (1986).

299. Adler, supra note 17, at 323; see also Skeel, supra note 18, at 483 (expanding on Adler's discussion of chameleon equity).

300. Bradley \& Rosenzweig, supra note 17, at 1078.

301. Id.; Adler, supra note 17, at 312.

302. LoPucki, supra note 17; Warren, supra note 17; Whitman et al., supra note 17.

303. For a review and an in-depth analysis of the debate, see SKEEL, supra note 3, at $102-05$.

304. See Tabb, supra note 268, at 804 . 
Rather, we believe contingent capital could supplement bankruptcy proceedings involving failing financial institutions.

The EU Commission ${ }^{305}$ and other national European regulators ${ }^{306}$ suggest using contingent capital in the reorganization of financial institutions. These proposals have the potential to reenergize and change the debate on contingent capital in corporate reorganization. Given the realities of bankruptcy proceedings and the attempt by all distressed businesses to seek workout agreements with creditors, ${ }^{307}$ Professor Charles Tabb observes that the proper question should not be whether reorganization has any benefit over liquidation but rather why reorganization requires court supervision. ${ }^{308}$ Workout agreements often fail and court supervision continues to be necessary because of the holdout of the dissenting creditor and the creditor's ultimate goal of collecting more than other creditors. ${ }^{309}$

Strategic behavior should also not be excluded in the context of the conversion of contingent capital in the current discussion on bank reorganization. However, contingent capital in bank reorganization presents itself as a form of reorganization without court supervision and prior to any formal statutorily regulated procedure. In addition, the "holdout problem" does not arise. The majority of CCS holders, or CCS holders and shareholders combined, determine corporate governance after conversion and prior to resolution. A sole holdout of consent will therefore not enable any creditor to collect more than any other creditor. Instead, the holdout creditor who is a shareholder after debt conversion will share in potential losses proportionate to his or her equity ownership. Accordingly, contingent capital could be a supplement to any bankruptcy proceeding, including reorganization under court supervision or liquidation. This is of particular significance in the United States where banks are not eligible to file for protection under Chapter 11 or have access to similar reorganization procedures. More importantly, the Dodd-Frank Act favors orderly liquidation and wind-down of financial institutions over reorganization. $^{310}$ Contingent capital has specific importance in this context. Contingent capital may help stabilize large financial firms by providing an option to reorganize pre-liquidation while allowing a

305. DG WORKING DOCUMENT, supra note 8.

306. See supra note 34 and accompanying text.

307. Tabb, supra note 268, at 804-07.

308. Id. at $812-15$.

309. Id. at 804-07.

310. Dodd-Frank Wall Street Reform and Consumer Protection Act § 214, 12 U.S.C. § 5394 (Supp. IV 2010) (“All financial companies put into receivership under this title shall be liquidated. No taxpayer funds shall be used to prevent the liquidation of any financial company under this title.”); see also SKEEL, supra note 3, at 138 (noting that "the framework is designed with liquidation in mind"). 
bank to be managed as a going concern. At the same time, it provides the option of staying in the market place after returning to profitability.

\section{CONCLUSION}

Systemically significant banks and financial markets in the United States could benefit from considering contingent capital as a preventive tool as well as a tool before resolution. Although we recognize that there are many open issues in implementing contingent capital in Europe and the United States and that determining the optimal calibration of design features and multiple triggers will require significant additional research, the proposal in this Article suggests the creation of contingent capital as a hybrid tool between prevention, reorganization, and bankruptcy. Combining contingent capital proposals with elements of bankruptcy concepts could bridge the gap between corporate governance, prevention, reorganization, and bankruptcy, while creating the right set of incentives for the respective constituents. As a hybrid, it could fill many of the open issues and create synergies for the optimal calibration of design features. Introducing a quasi-preparation stage for bankruptcy, independent of management decisions or corrective action by regulators, our proposal could increase the application of contingent capital in the United States and Europe. The proposal would work seamlessly with the regulatory frameworks proposed by the EU Commission and could provide U.S. policymakers with a new perspective on the multiple uses of contingent capital. 
